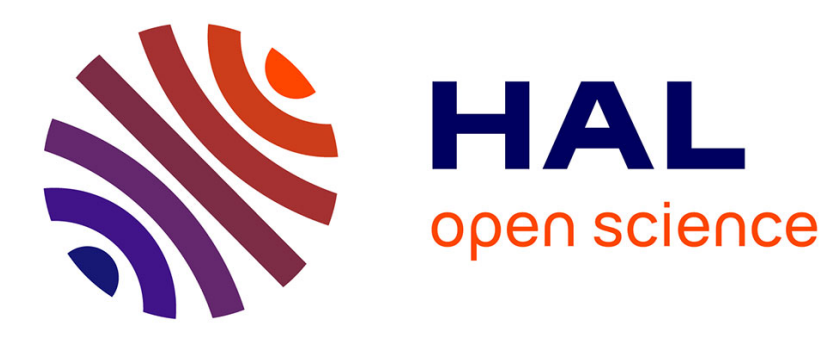

\title{
Volcanism in a compressional Andean setting: A structural and geochronological study of Tromen volcano (Neuquèn province, Argentina)
}

Olivier Galland, Erwan Hallot, Peter R. Cobbold, Gilles Ruffet, Jean de Bremond d'Ars

\section{To cite this version:}

Olivier Galland, Erwan Hallot, Peter R. Cobbold, Gilles Ruffet, Jean de Bremond d'Ars. Volcanism in a compressional Andean setting: A structural and geochronological study of Tromen volcano (Neuquèn province, Argentina). Tectonics, 2007, 26 (4), pp.TC4010. 10.1029/2006TC002011 . insu-00180007

\section{HAL Id: insu-00180007 https://hal-insu.archives-ouvertes.fr/insu-00180007}

Submitted on 29 Jun 2016

HAL is a multi-disciplinary open access archive for the deposit and dissemination of scientific research documents, whether they are published or not. The documents may come from teaching and research institutions in France or abroad, or from public or private research centers.
L'archive ouverte pluridisciplinaire HAL, est destinée au dépôt et à la diffusion de documents scientifiques de niveau recherche, publiés ou non, émanant des établissements d'enseignement et de recherche français ou étrangers, des laboratoires publics ou privés. 


\title{
Volcanism in a compressional Andean setting: A structural and geochronological study of Tromen volcano (Neuquén province, Argentina)
}

\author{
Olivier Galland, ${ }^{1,2}$ Erwan Hallot, ${ }^{1}$ Peter R. Cobbold, ${ }^{1}$ Gilles Ruffet, ${ }^{1}$ \\ and Jean de Bremond d'Ars ${ }^{1}$ \\ Received 28 June 2006; revised 6 February 2007; accepted 16 March 2007; published 2 August 2007.
}

[1] We document evidence for growth of an active volcano in a compressional Andean setting. Our data are surface structures and ${ }^{39} \mathrm{Ar}-{ }^{40} \mathrm{Ar}$ ages of volcanic products on Tromen volcano. Tromen is an active back-arc volcano in the Andean foothills of Neuquén province, Argentina. Its volcanic products are unconformable upon Mesozoic strata of the Neuquén basin. The volcano straddles a N-S trending pop-up, which formed during E-W shortening. The main underlying structures are eastward verging thrusts. Their traces curve around the eastern foot of the volcano. Minor folds and faults also occur in the volcanic cover of Tromen, as a result of E-W shortening. New ${ }^{39} \mathrm{Ar}^{40} \mathrm{Ar}$ ages for these volcanic rocks are younger than $2.27 \pm 0.10 \mathrm{Ma}$ and show that Tromen has been active almost continuously from the late Pliocene to the Holocene. We conclude that volcanism and thrusting have been coeval and that magma must have reached the surface in a tectonic setting of horizontal compression. Our results have wider implications for magmatic processes in such settings. Citation: Galland, O., E. Hallot, P. R. Cobbold, G. Ruffet, and J. de Bremond d'Ars (2007), Volcanism in a compressional Andean setting: A structural and geochronological study of Tromen volcano (Neuquén province, Argentina), Tectonics, 26, TC4010, doi:10.1029/2006TC002011.

\section{Introduction}

[2] Volcanic activity is especially common in areas of extensional tectonics, and notably so at divergent plate boundaries. In principle, such a setting should induce vertical hydraulic fractures, along which magma rises directly through the upper crust, to the surface [Hubbert and Willis, 1957; Sibson, 2003]. This is borne out by field observations, for example, in the rift system of Iceland [Gudmundsson, 1984; Helgason and Zentilli, 1985].

\footnotetext{
${ }^{1}$ Géosciences Rennes, UMR 6118, CNRS, Université de Rennes 1 , Rennes, France.

${ }^{2}$ Now at Physics of Geological Processes, Universitet i Oslo, Oslo, Norway.

Copyright 2007 by the American Geophysical Union. 0278-7407/07/2006TC002011
}

[3] In contrast, a context of crustal thickening, where the least principal stress is vertical, should impede the rise of magma [Watanabe et al., 1999; Sibson, 2003] and produce horizontal hydraulic fractures [Hubbert and Willis, 1957; Sibson, 2003]. Under these conditions, some authors have argued that volcanic activity is infrequent, if not absent [Glazner, 1991; Hamilton, 1995]. Nevertheless, volcanism and compressional tectonics are coeval in many places on the Earth's surface, for example in the Andes [Allmendinger et al., 1997; Lamb et al., 1997], and in Japan [Townend and Zoback, 2006].

[4] Because it is intuitive that extension provides room for magma, it is sometimes assumed that such extension is a necessity [Glazner, 1991; Hamilton, 1995]. For example, in the Andes the volcanic arc has been interpreted as a result of local extension [e.g., de Silva, 1989; Hamilton, 1995]. However, Andean volcanoes have been active in a regional context of horizontal compression since $50 \mathrm{Ma}$ or earlier [Allmendinger et al., 1997; Lamb et al., 1997; Kendrick et al., 1999; Kendrick et al., 2001; Hindle et al., 2002]. In such a setting, how has magma risen to the surface? Have the volcanic edifices been subject to shortening? What has happened at depth?

[5] In the Andes, there have been many descriptions of volcanoes in close proximity to faults. Strike-slip faults, and lineaments that are transverse to the orogen, would appear to be the most common [Marrett and Emerman, 1992; Boudesseul, 1997; Matteini et al., 2002a, 2002b; Petrinovic et al., 2006]. However, some Andean volcanoes are close to thrust faults. A good example is El Reventador volcano in Ecuador, which formed in a compressional or transpressional setting [Tibaldi, 2005]. Other examples along the Andean Cordillera are Guagua Pichincha in Ecuador [Legrand et al., 2002], Taapaca in Chile [Clavero et al., 2004], Socompa in Chile [van Wyk de Vries et al., 2001], and Tromen in Argentina [Kozlowski et al., 1996; Marques and Cobbold, 2002, 2006; Galland et al., 2005]. In the main volcanic arc of Neuquén province, Folguera et al. [2004] have described thrusts and folds in basaltic lava flows of Pleistocene age. However, the relationships of volcanoes to nearby thrust faults remain enigmatic and insufficiently explored.

[6] Elsewhere, there is evidence that some intrusions, which formed at depth in a context of crustal thickening and now at the surface as a result of exhumation (see review by Hutton [1997]), have been associated with major thrust faults. Good examples are the Boulder Batholith of Colo- 
rado [Kalakay et al., 2001; Lageson et al., 2001] and the Idaho-Bitterroot Batholith in the United States [Foster et al., 2001]. Could such associations be representative of what happens at the roots of some Andean volcanoes?

[7] In this paper, we describe structural and geochronologic evidence that Tromen volcano formed during active compression in an Andean back-arc context. Tromen volcano rises to $4000 \mathrm{~m}$ in a thick-skinned fold-and-thrust belt, on the western margin of the Neuquén basin, Argentina (Figure 1). Its volcanic products are unconformable upon Mesozoic strata. The major eastward verging Tromen thrust dips beneath the volcano and bends around its base (Figure 2) [Kozlowski et al., 1996; Marques and Cobbold, 2002]. We describe the relationships between the volcanic products of Tromen and the tectonic structures beneath or within it. To constrain the timing of volcanic and tectonic events, we have obtained new ${ }^{39} \mathrm{Ar}^{40} \mathrm{Ar}$ ages on the volcanic rocks. On the basis of our results, we discuss possible processes governing the rise of magma and the eruptions of Tromen during horizontal compression.

\section{Geological Setting}

[8] The Neuquén basin lies in NW Patagonia, to the east of the Andean Cordillera (Figure 1). It contains up to 5000 meters of Mesozoic strata. Synrift sediments of the Pre-Cuyo group and organic-rich mudstone of the Los Molles formation accumulated during a phase of late Triassic to early Jurassic extension that heralded the breakup of Gondwana (Figure 2c) [Vergani et al., 1995; Franzese and Spalletti, 2001; Franzese et al., 2003]. Jurassic and Early Cretaceous strata marked a phase of postrift subsidence on the Pacific margin. The Jurassic Lotena formation is mainly of detrital origin, but includes some carbonates (La Manga member). After the evaporitic Auquilco formation came sandstone of the Tordillo formation. The late Jurassic saw a second accumulation of organic-rich mudstone (Vaca Muerta formation). After another sandstone interval (Mulinchinco formation) came a third thickness of organic-rich mudstone (Agrio formation). The evaporitic Huitrín formation then marked the end of marine conditions. The mudstones of the Los Molles, Vaca Muerta and Agrio formations are the main source rocks for hydrocarbons in the Neuquén Basin. During the Late Cretaceous, continental red beds (Neuquén Group) accumulated regionally in a foreland setting [Cobbold and Rossello, 2003]. During the Cenozoic, continental sediment and volcanic rocks accumulated here and there within the basin.

[9] Several periods of tectonic inversion have been recognized in the Neuquén basin. They correlate with the Peruvian, Incaic, and Quechua phases of Andean orogeny [Groeber, 1929; Cobbold and Rossello, 2002, 2003]. The Peruvian phase (Aptian to Campanian) was responsible for E-W shortening and resulted in folds and thrusts, trending N-S, including the Andacollo-Loncopué Fault System (Figure 1). This first phase also resulted in a regional unconformity between the Agrio and Huitrín formations. The foreland basin then filled with continental sediment up to $2500 \mathrm{~m}$ thick. During the Incaic phase (Eocene), oblique convergence at the Pacific margin led to right-lateral transpression and strike-slip faulting [Cobbold and Rossello, 2003]. It also may have resulted in the emplacement of a swarm of NE trending bitumen dikes [Cobbold et al., 1999]. Some authors argue that the Incaic phase was followed by an extensional phase of Oligocene to early Miocene age [Jordan et al., 2001; Folguera et al., 2002], but Cobbold and Rossello [2002, 2003] have discussed evidence for compression during these periods. The Quechua phase (Neogene) resulted from more frontal convergence at the Pacific margin. It reactivated previous structures, and formed new ones (such as the Tromen thrust, Figure 1 [Kozlowski et al., 1996; Cobbold and Rossello, 2003]). The Incaic and Quechua phases were both contemporaneous with periods of rapid convergence at the Pacific margin of South America [Pardo-Casas and Molnar, 1987; Somoza, 1998; Cobbold and Rossello, 2003].

[10] Because Neogene deposits are scarce, it is not clear how long compressional deformation has lasted. According to Kozlowski et al. [1996] and Folguera et al. [2002], it ended before $12 \mathrm{Ma}$. More recently, Folguera et al. [2005, 2006], Ramos and Folguera [2005], Kay et al. [2006a] have argued that compressional deformation stopped during the early Pliocene, and that active tectonics is extensional. However, GPS measurements [Klotz et al., 2001], in situ stress measurements [Guzmán et al., 2005], and structural and geomorphological data [Cobbold and Rossello, 2002, 2003; Folguera et al., 2004, 2005; Galland, 2005; Galland et al., 2005] provide evidence for current horizontal compression.

[11] In Neuquén province, the cordillera and its foreland have a long history of magmatic activity. During the Eocene, a thick pile of andesite lava flows accumulated to the west of the Andacollo-Loncopué Fault System (Figure 1) [Jordan et al., 2001], and shallow level intrusions were emplaced in the Agrio fold belt [Llambias and Rapela, 1988; Cobbold and Rossello, 2003]. During the Oligocene and Miocene, the magmatic arc migrated eastward [Vergara and Munizaga, 1974; Suarez and Emparan, 1995; Muñoz et al., 2000]. To the north of the Cortaderas fault zone (Figure 1), magmatic activity with an arc geochemical signature reached as far as $500 \mathrm{~km}$ east of the trench [Kay et al., 2006b; Kay and Copeland, 2006]. It accounted for $1000 \mathrm{~m}$ of basaltic lava flows in the Huantraico syncline, $200 \mathrm{~km}$ east of the frontal volcanic arc (Figure 1) [Ramos and Barbieri, 1988; Kay and Copeland, 2006], and early activity of Chachahuén volcano (Figure 1) [Kay et al., 2006a, 2006b]. Then, during the Pliocene and Holocene, magmatism with an arc geochemical signature migrated westward and concentrated close to the modern volcanic front [Vergara and Munizaga, 1974; Hickey et al., 1986; Folguera et al., 2002]. However, east of the main arc, large shield-like volcanoes, such as Auca Mahuida, Payun Matru and Tromen (Figure 1), have back-arc (intraplate-like) geochemical signatures [Llambias et al., 1982; Saal et al., 1993; Kay et al., 2006a].

[12] Although Tromen is a back-arc volcano, it is close to the current magmatic arc (Figure 1). At $3969 \mathrm{~m}$, the summit of Tromen dominates the western Neuquén basin. Its main 


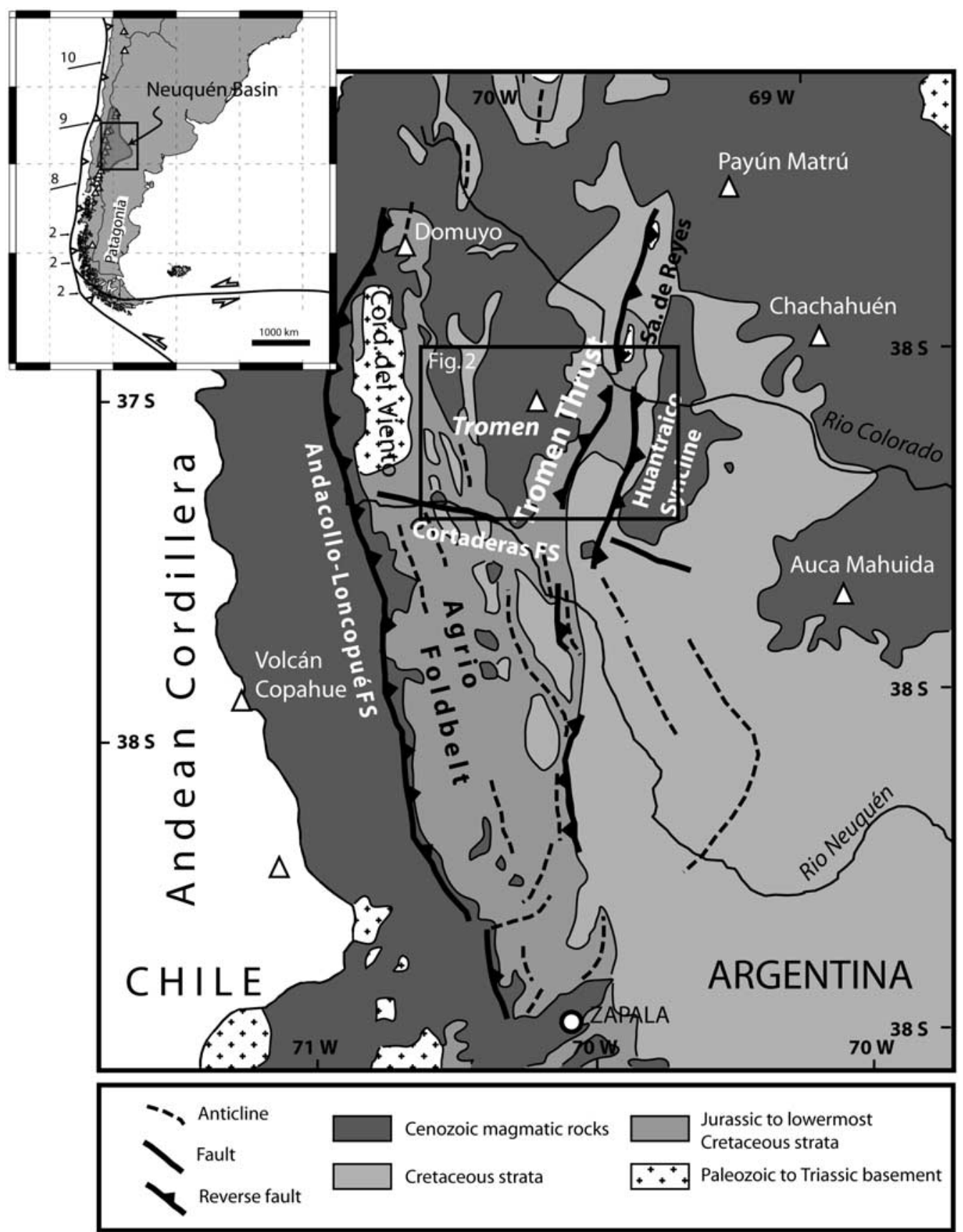

Figure 1. Geological map of Neuquén basin, northwestern Neuquén province (modified after Cobbold and Rossello [2003]). Map shows main groups of sedimentary and magmatic rocks, major tectonic structures, and principal volcanoes (white triangles). FS denotes fault system. Box indicates area around Tromen volcano (Figure 2). Inset shows large-scale tectonic setting, current velocity vectors for Nazca plate relative to South America (numbers in $\mathrm{cm} / \mathrm{yr}$ ), and principal volcanoes of the Andes (white triangles).

period of activity spanned the Pleistocene and Holocene [Zollner and Amos, 1973; Holmberg, 1975; Llambias et al., 1982]. However, there are strong indications that Tromen has continued to be active in very recent, and even historical times. Its northern crater is well preserved and contains deposits of sulphur [Zollner and Amos, 1973]. The uppermost basaltic lava flows, which erupted from it, have fresh blocky surfaces that are free of vegetation. A historical eruption in 1822 has been reported [Simkin and Siebert, 1994], although we have no independent evidence for it. 

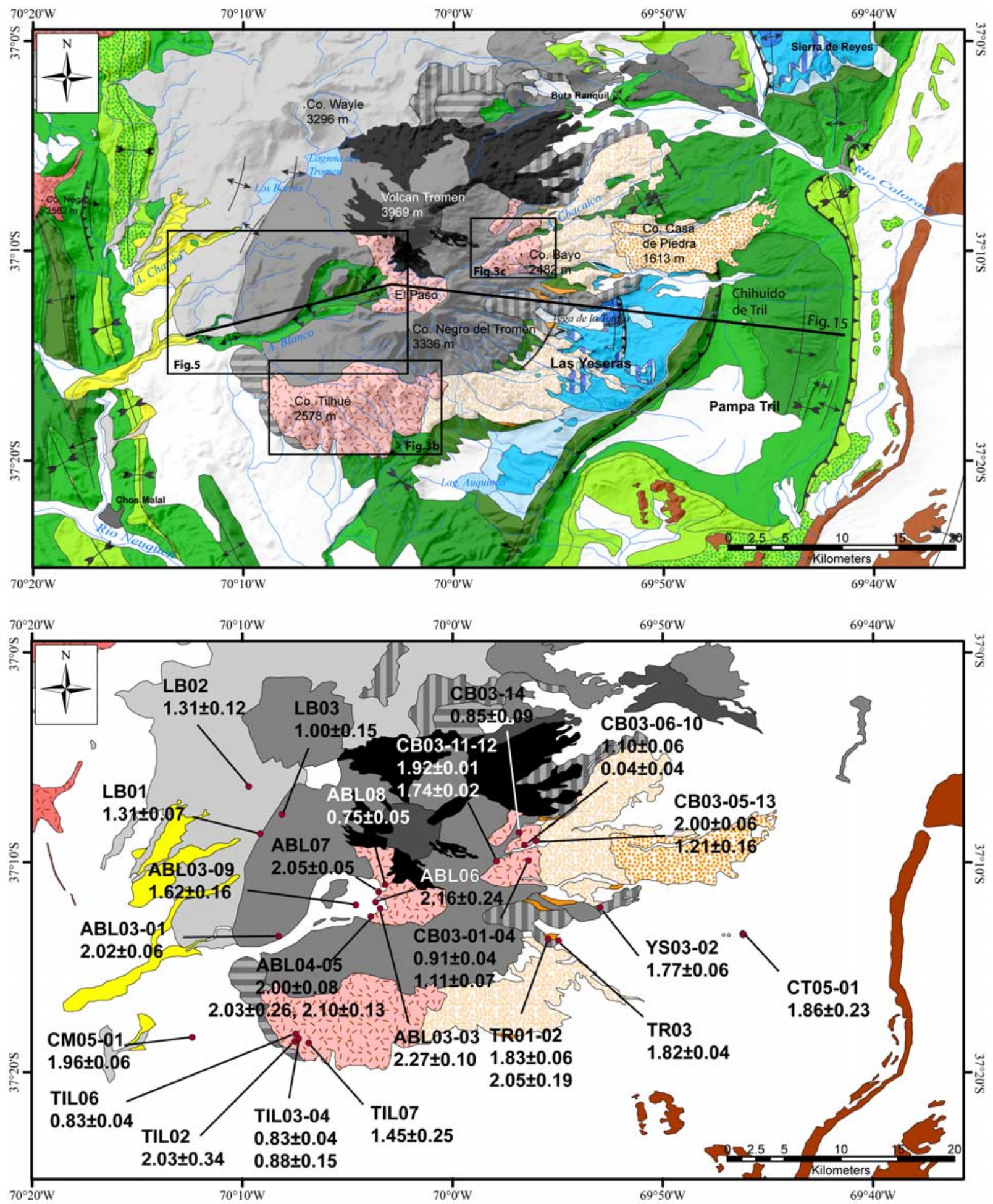

Figure 2. (a) Geological map of Tromen volcano (modified after Zollner and Amos [1973] and Holmberg [1975]). Boxes indicate areas of more detailed study (Figures 3b, 3c, and 5). For E-W cross section of volcano, see Figure 15. (b) Map of volcano-sedimentary formations of Tromen area. Red circles and associated numbers refer to samples for dating (Table 1) and ages obtained. (c) Stratigraphic column and map legend. 


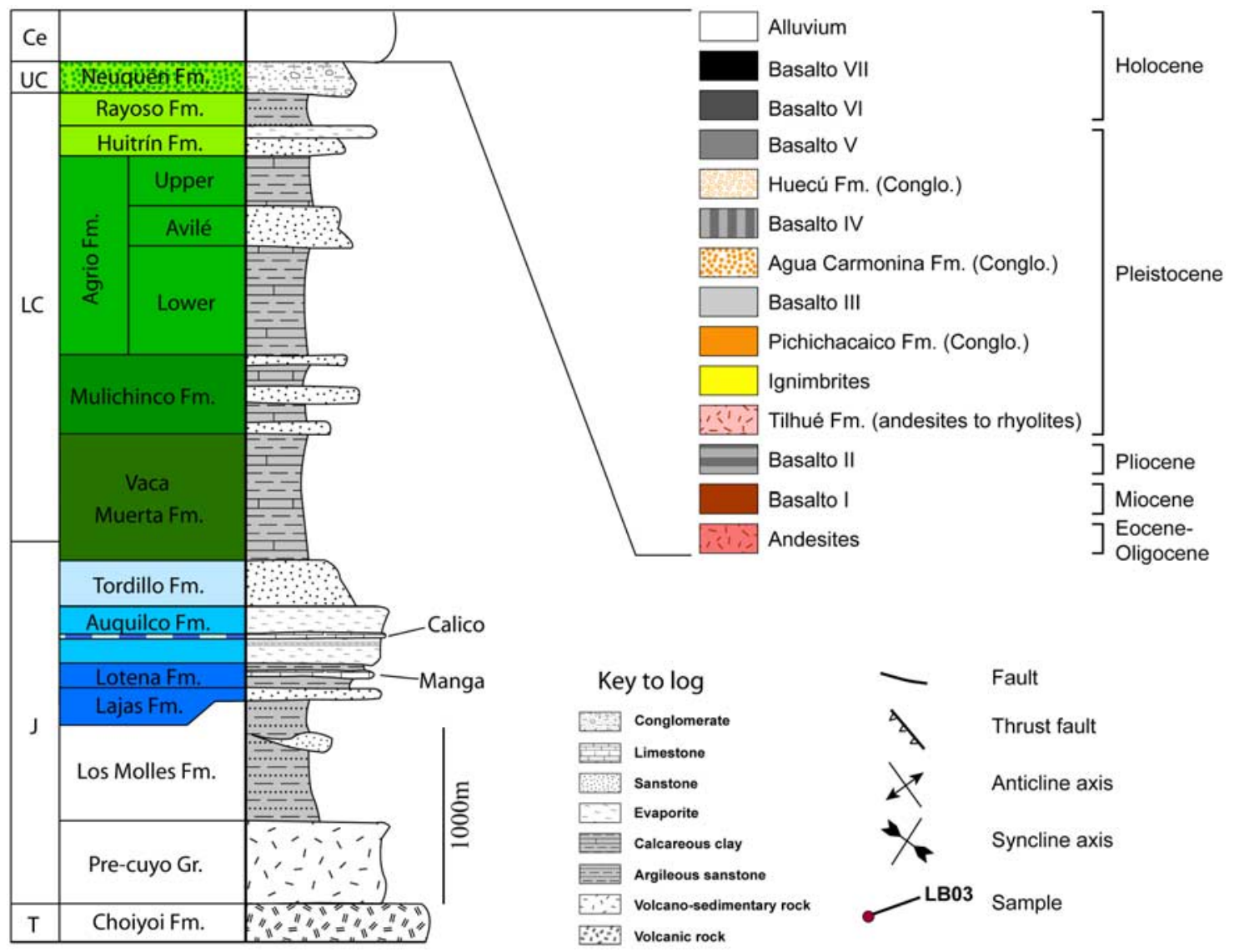

Figure 2. (continued)

Between 1751 and 1752, a Jesuit priest, Bernardo Havestadt, went near the twin peaks of Tromen volcano and wrote, "the smoke that they sometimes throw out is so thick, black, and abundant, that, even at noon, it darkens the place, and transforms the day into night" (our translation from the Spanish [Havestadt, 1752]).

[13] The volcanic products of Tromen are unconformable upon a deformed Mesozoic substrate (Figure 2) [Zollner and Amos, 1973; Llambias et al., 1982]. The main structure close to the volcano is the Tromen thrust (Figure 2a) [Holmberg, 1975; Kozlowski et al., 1996].

\section{Products of Tromen}

[14] We describe the main products of Tromen, and the petrological features of the volcanic rocks that we sampled for ${ }^{39} \mathrm{Ar}-{ }^{40} \mathrm{Ar}$ dating.

[15] At the surface, the most voluminous products of Tromen are basaltic lava flows (Basalto formations, Figure 2 [Zollner and Amos, 1973; Holmberg, 1975; Llambías et al., 1982]). However, andesitic to rhyolitic lavas and domes are dominant in some places (Pleistocene Tilhué formation, Figure 2 [Zollner and Amos, 1973; Holmberg, 1975]). An early geochemical analysis of Tromen lavas yielded a calcalkaline signature [Llambias et al., 1982]. Later studies indicated that the Tromen lavas differ from those of the main volcanic arc: they are more alkaline and have intraplate-like signatures, like the lavas of other back-arc volcanoes in the area [Stern et al., 1990; Saal et al., 1993; Kay et al., 2006a].

[16] There are also several deposits of conglomerate on Tromen (Pichichacaico, Huecú, and Agua Carmonina formations, Figure 2). Mostly they contain pebbles or blocks of volcanic material.

[17] Although Miocene to Pliocene basalts (Basalto I and Basalto II formations [Zollner and Amos, 1973; Holmberg, 1975]) crop out in the general area (Figure 2), there is no direct evidence that they erupted from Tromen. In fact, the Basalto I formation, which extends as much as $100 \mathrm{~km}$ to the east of Tromen, appears to be older [Groeber, 1929]. In the Tromen area, the Basalto 1 formation appears to derive from a partly eroded volcanic center to the south of the Huantraico syncline (Figure 1) [Holmberg, 1975; Ramos and Barbieri, 1988]. Thus we shall consider neither of these formations any further.

\subsection{Domes of Andesite, Dacite, or Rhyolite}

[18] Traditionally, the andesite, dacite and rhyolite of Tromen have been assigned to the Tilhué formation [Groeber, 1929; Zollner and Amos, 1973; Holmberg, 1975]. These rocks crop out at (1) Cerro Tilhué in the south, (2) Cerro Bayo in the east, and (3) El Paso, a central 
a
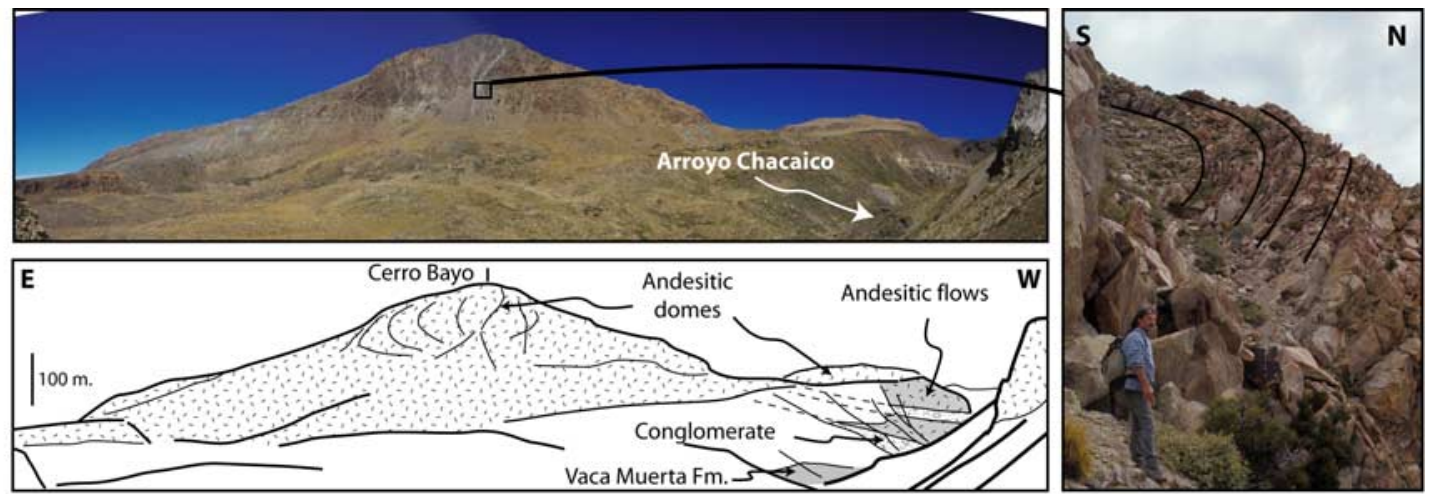

b

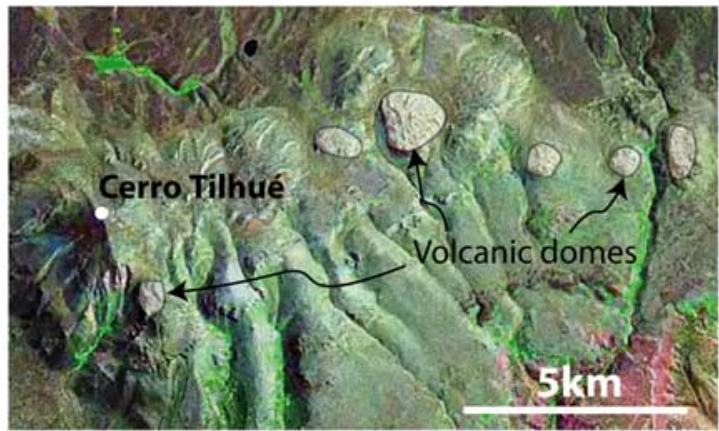

C

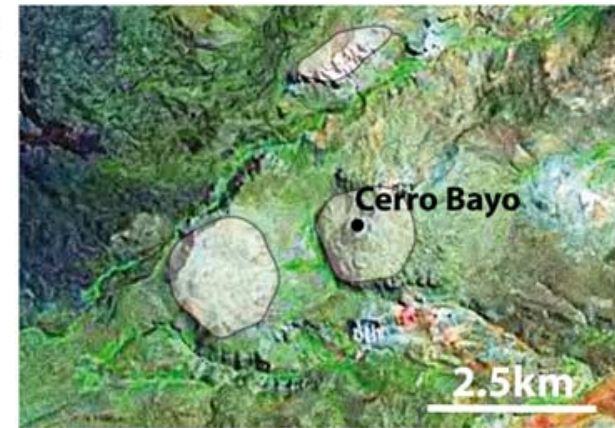

Figure 3. Domes of the Tilhué formation. (a) Photograph and line drawing of Cerro Bayo, eastern flank of Tromen (box, Figure 2a). Large andesite dome is unconformable upon Vaca Muerta formation, conglomerate, and intercalated andesite lava flows. Flow banding (photograph, right) is continuous around dome. (b) Satellite image of Cerro Tilhué. Subcircular volcanic domes lie along E-W lineament. (c) Satellite image of Cerro Bayo. Volcanic domes lie along another E-W lineament.

pass between the western and eastern flanks of the volcano (Figures 2 and 3). In the field, these rocks form massive domes, 100 to $300 \mathrm{~m}$ thick, which are unconformable upon the Mesozoic substrate. The domes have a marked internal flow banding, which is continuous around them, despite strong dip variations (Figure 3a). We interpret these domes to be extrusive. Although they were originally described as extrusive [Groeber, 1929; Zollner and Amos, 1973; Holmberg, 1975], the map legend from Zollner and Amos [1973] has them as intrusive bodies, presumably by mistake.

[19] At Cerro Tilhué, several andesite domes lie along an E-W lineament (Figure 3b). In thin section (samples TIL02, TIL03, TIL06, TIL07; Table 1), the texture is porphyritic, vesicular, and holohyaline to spherulitic (Figure 4a). Phenocrysts are 3 to $5 \mathrm{~mm}$ long, and account for 10 to $30 \mathrm{vol} \%$ of the rock. They consist mostly of plagioclase $\left(\mathrm{An}_{20-30}\right.$, oligoclase), clinopyroxene, oxyhornblende and biotite, the latter two being rimmed by opaque minerals.

[20] At Cerro Bayo, the Tilhue formation is composite. The oldest rocks are two conglomeratic beds, overlain by two flow units of andesite lava, $50 \mathrm{~m}$ thick (Arroyo Chacaico valley; Figure $3 \mathrm{a}$; see also cross section $\mathrm{B}-\mathrm{B}^{\prime}$ in Figure 13 in section 5.2). Unconformable upon them are domes of andesite, dacite or rhyolite, 200-300 m thick. The andesite lava flows have a porphyritic to glomeroporphyritic texture (samples CB03-11 and CB03-12). Phenocrysts
(20 to $40 \mathrm{vol} \%$ ), in a microlitic mesostasis, are mostly of plagioclase $\left(\mathrm{An}_{45}\right.$, up to several $\mathrm{cm}$ in length), rich in inclusions. A few phenocrysts are of clinopyroxene. The two main domes, including Cerro Bayo, lie along an E-W lineament (Figure 3c). The texture is porphyritic, banded and vesicular. Phenocrysts, up to $5 \mathrm{~mm}$ long, are in a holohyaline to spherulitic groundmass (Figure $4 \mathrm{~b}$ ). In the andesite domes (samples CB03-01, CB03-04 and CB03-14; Table 1), the phenocryst content is 20 to $40 \mathrm{vol} \%$; the main phase is plagioclase $\left(\mathrm{An}_{20-30}\right)$, with minor oxyhornblende and biotite, both rimmed by opaque minerals. In the dacites and rhyolites (samples CB03-05, CB03-06 and CB03-13; Table 1 ), the phenocryst content is 5 to $10 \mathrm{vol} \%$. They are mainly of plagioclase $\left(\mathrm{An}_{25}\right)$ and alkali feldspar (sanidine or anorthoclase).

[21] At El Paso, andesitic to rhyodacitic domes are unconformable upon Mesozoic strata. Several domes are overlain by younger flows of basaltic lava. The texture of the rocks (samples ABL05, ABL08 and ABL03-03; Table 1) is porphyritic to glomeroporphyritic, mostly vesicular and banded. The groundmass is holohyaline, sometimes finegrained (Figure 4c). Phenocrysts (15 to $40 \mathrm{vol} \%$, up to $5 \mathrm{~mm}$ long) are mostly of plagioclase $\left(\mathrm{An}_{25-50}\right)$, with minor clinopyroxene, oxyhornblende and biotite. 


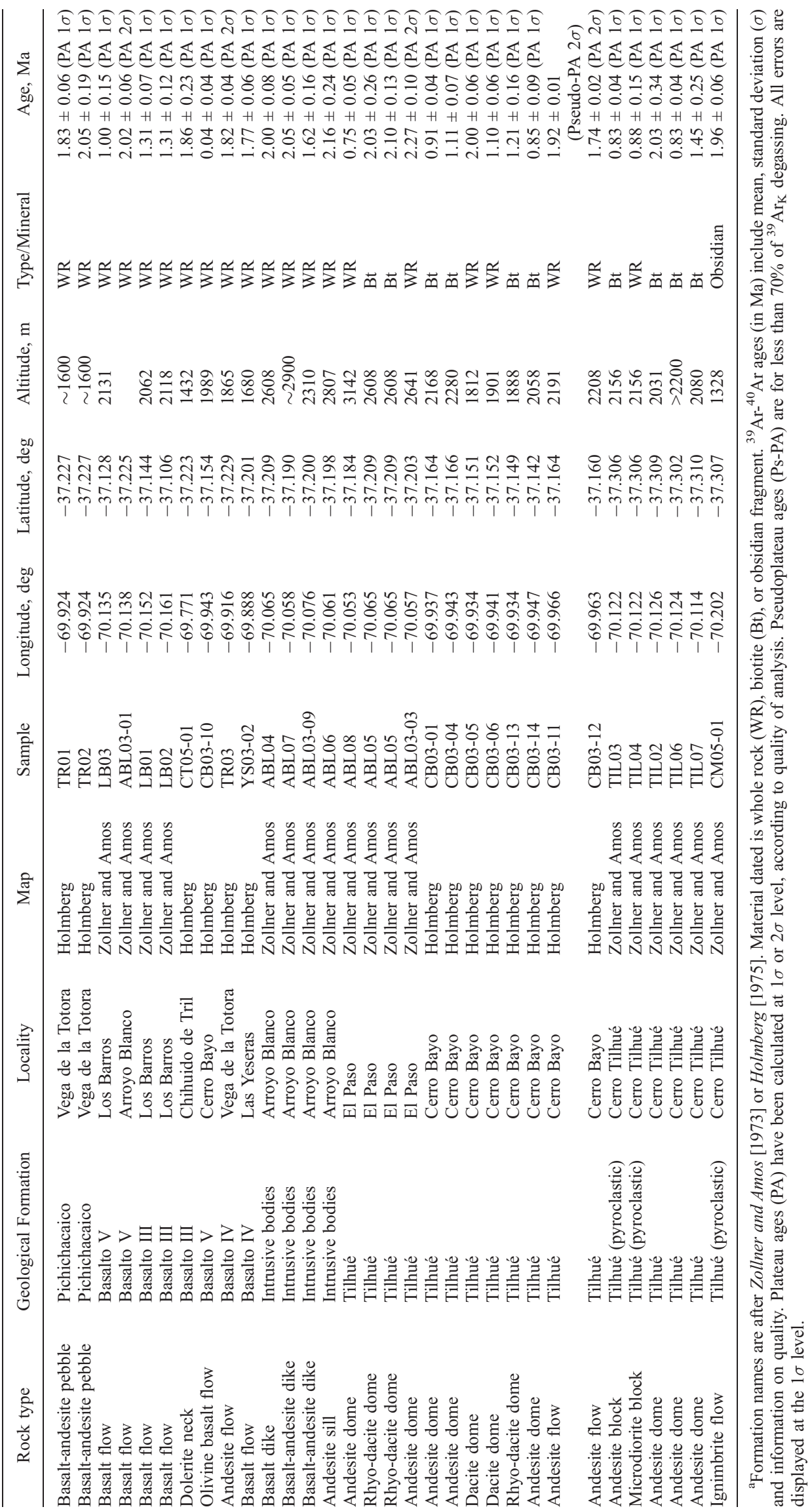


a

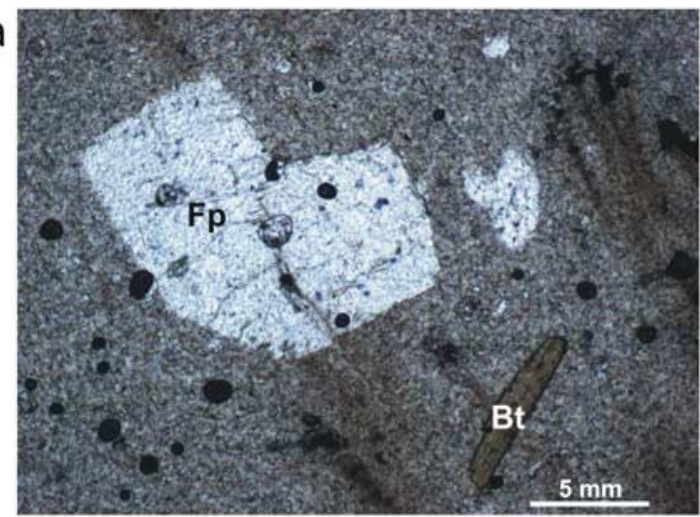

C

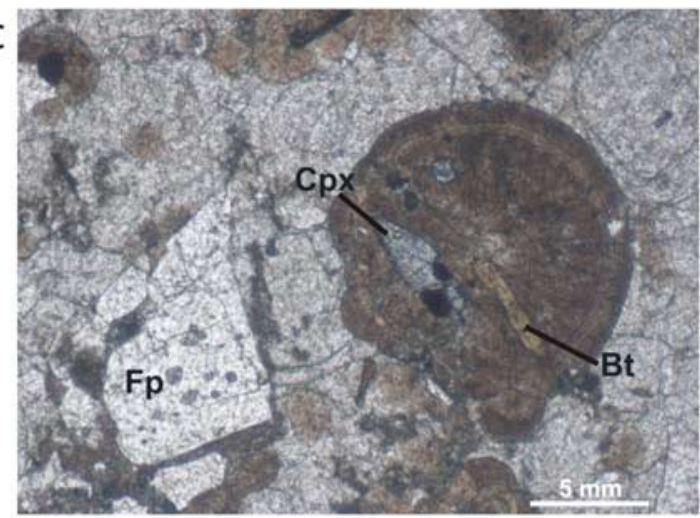

e

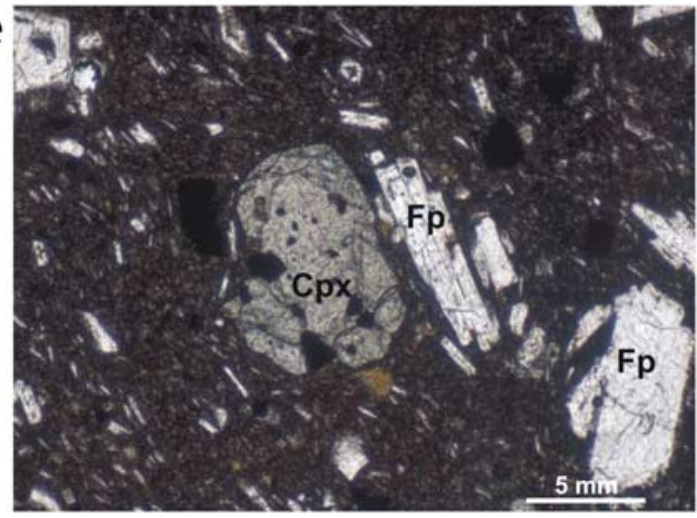

b

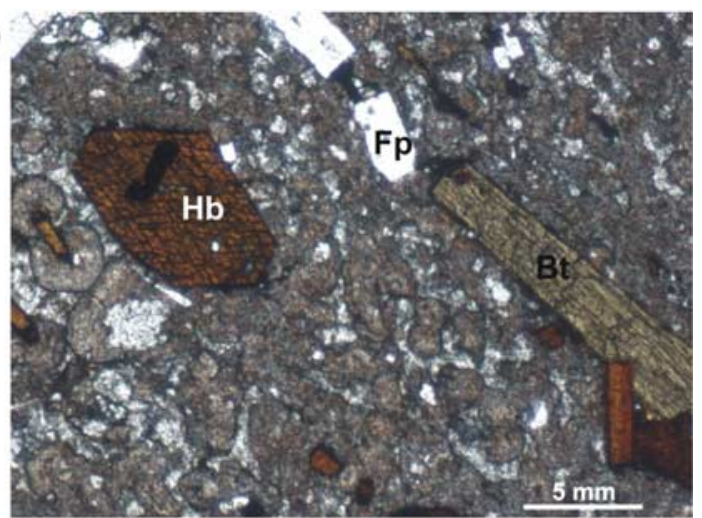

$\mathrm{d}$

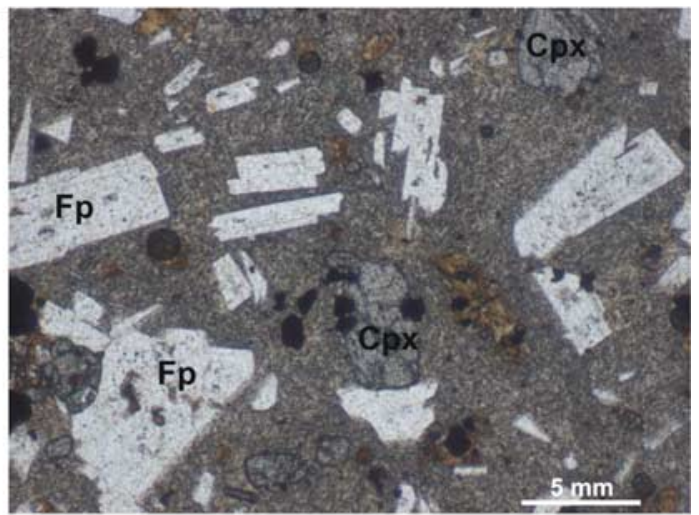

f

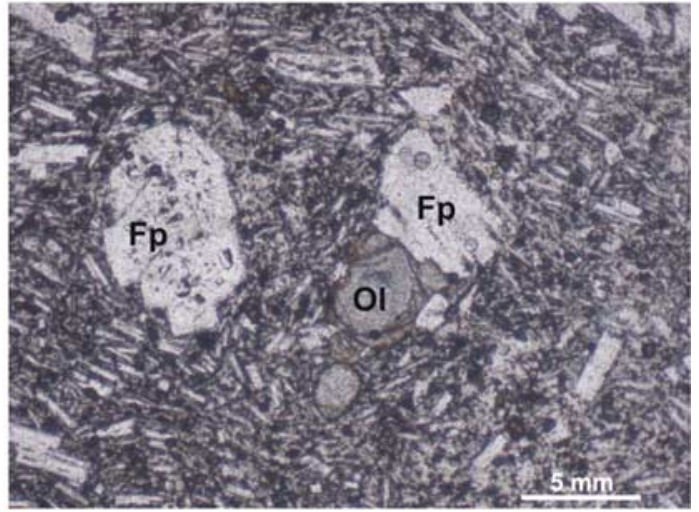

Figure 4. Representative thin sections of volcanic rocks from Tromen (PPL). Labeled minerals are plagioclase feldspar $(\mathrm{Fp})$, oxyhornblende $(\mathrm{Hb})$, biotite $(\mathrm{Bt})$, clinopyroxene $(\mathrm{Cpx})$, and olivine $(\mathrm{Ol})$. (a) Sample TIL01, Tilhué formation, Cerro Tilhué. Notice spherulitic matrix. (b) Sample CB03-14, Tilhué formation, Cerro Bayo. Notice spherulitic texture. (c) Sample ABL05, Tilhué formation, El Paso. (d) Sample ABL07, E-W dike. (e) Sample LB03, Basalto V formation. (f) Sample TR02, pebble within conglomerate of Pichichacaico formation.

\subsection{Pyroclastic Deposits}

[22] Pyroclastic deposits, including ignimbrites, have been reported on the western flank of Tromen [Zollner and Amos, 1973]. The ignimbrites contain white lapilli of pumice and obsidian fragments. They crop out widely along the Arroyo Chapúa and lower Arroyo Blanco (Figure 2). In the upper Arroyo Blanco, they fill paleovalleys in Mesozoic strata (outcrop I1, Figure 5). Later paleovalleys, cutting into the same ignimbrite, contain thick conglomerate. According to Zollner and Amos [1973], the pyroclastic deposits correlate with the felsic domes of the Tilhué formation. This is also consistent with the geochemical compositions of the rocks [Kay et al., 2006a]. However, we were not able to establish any continuity or correlation between them. The 

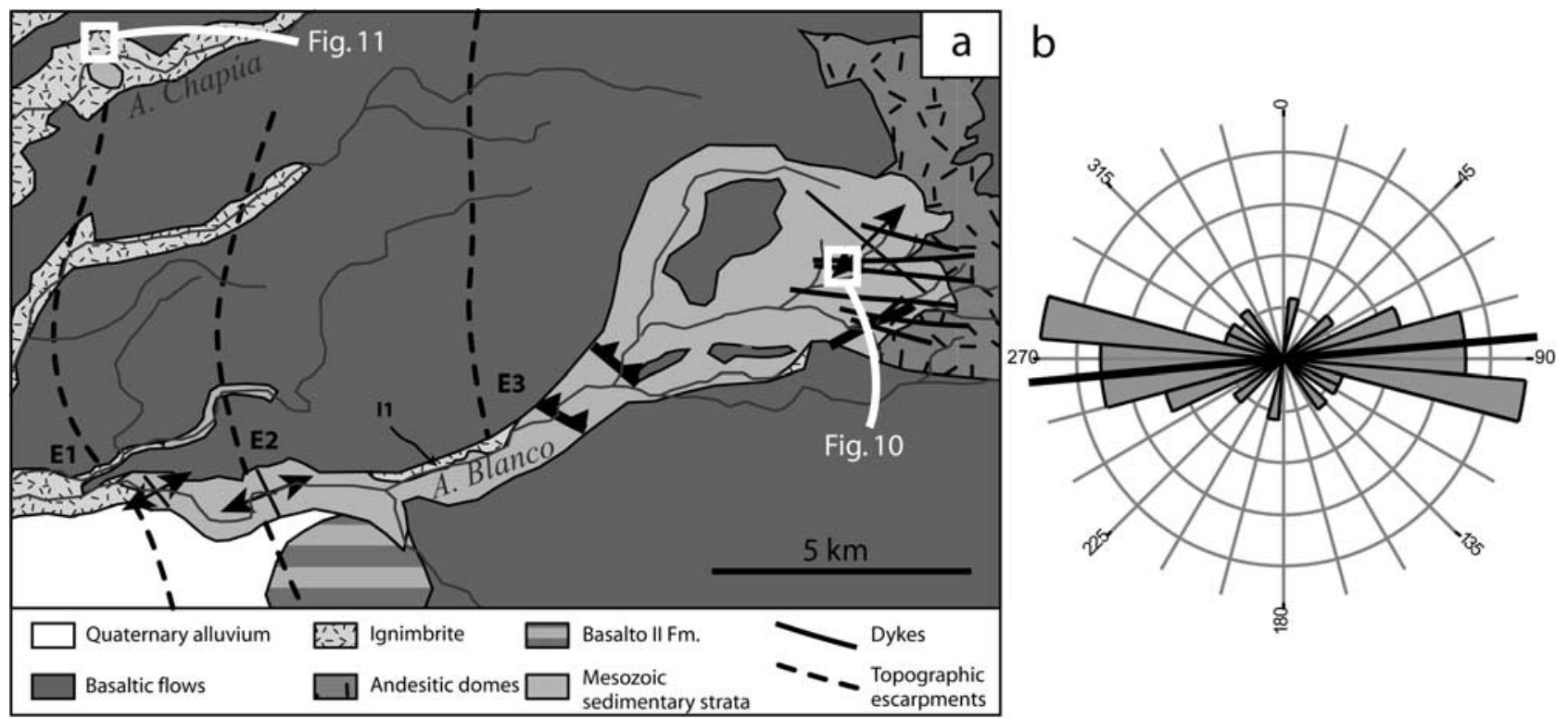

Figure 5. (a) Detailed geological map of Arroyo Blanco valley. Notice outcropping cliffs of ignimbrite (not visible in Figure 2) and E-W dikes in upper reaches of valley. White boxes locate Figures 10 and 11. Dashed traces (E1, E2, and E3) indicate topographic escarpments (see also Figure 8). Outcrop I1 is of pyroclastic deposits (Figure 9). (b) Rose diagram for strikes of 17 dikes in upper reaches of Arroyo Blanco. Mean strike is almost E-W.

source of the ignimbrites is not clear. They could have come from Tromen, or from other volcanic centers in the general area. For example, Payun Matru to the north (Figure 1) [Dessanti, 1973, 1975] has emitted large amounts of pyroclastic material over distances of several hundred kilometers. Nevertheless, for dating, an obsidian pyroclast was selected (sample CM05-01, Table 1).

[23] Direct field evidence for volcanic explosions in the Tilhué formation is relatively rare. At Cerro Tilhué, small outcrops of pyroclastic material are close to the andesite domes. The deposits contain both lithic and andesitic fragments, up to $10 \mathrm{~cm}$ wide, within an ashy andesitic matrix. Some of the lithic fragments are rich in oxyhornblende and plagioclase and have a fine-grained texture (sample TIL04; Table 1). Near the domes of Cerro Bayo, some andesite flows are strongly banded breccias. Layers of andesite, a few centimeters thick and containing plagioclase phenoclasts in a holohyaline groundmass, alternate with discontinuous ashy layers. We take this association as evidence for partly explosive activity.

\subsection{Sills and Dikes}

[24] Immediately to the east of the Tromen thrust, an E-W dike, about $1 \mathrm{~m}$ wide, links four volcanic necks, three small ones and one large one (Chihuido de Tril; Figure 2). Zollner and Amos [1973] and Holmberg [1975] included these rocks in the Basalto III formation. The smaller necks have annular rims, containing flattened and vertically stretched vesicles, as well as radial polygonal jointing. The large neck now forms an eroded pinnacle, about $50 \mathrm{~m}$ wide and reaching a height of $1432 \mathrm{~m}$. The core is of dolerite. In thin section (sample CT05-01, Table 1) it contains rare phenocrysts of zoned plagioclase $\left(\mathrm{An}_{50-60}\right)$, olivine, or clinopyroxene, up to $2 \mathrm{~mm}$ in size. The groundmass is a network of plagioclase laths (up to $1 \mathrm{~mm}$ long and $0.25 \mathrm{~mm}$ wide), between microcrysts of euhedral olivine (partly replaced by clays) and clinopyroxene. Opaque minerals and acicular apatite are the main accessory phases. The nonequant minerals form a strong linear fabric, which is vertical, presumably as a result of extrusion. The annular rim of the Chihuido de Tril is finer grained and displays flow banding, a strong vertical lineation, radial polygonal cooling joints, and a few radial dikes. Adhering to the sides of the eroded neck are remnants of metamorphosed Mesozoic strata (Agrio, Huitrín and Rayoso formations).

[25] As mentioned by Groeber [1929], sills and subvertical dikes crop out in the eroded center and western flank of Tromen (upper Arroyo Blanco valley; Figure 5). Andesite sills (sample ABL06; Table 1) are parallel to folded Mesozoic strata (Mulichinco and Vaca Muerta formations). The texture is holohyaline and porphyritic. Phenocrysts (30 vol \%) are mostly of plagioclase $\left(\mathrm{An}_{25}\right)$, or of altered hornblende or biotite. Dikes up to $20 \mathrm{~m}$ thick strike almost E-W (Figure 5). They crosscut andesite sills, Mesozoic strata, and andesite domes of the Tilhué formation (Figure 5a). Late conglomerate is unconformable upon the eroded dikes and the ignimbrites. The dikes consist of andesite (samples ABL04, ABL07 and ABL03-09; Table 1). The texture is porphyritic, locally banded. The groundmass is microlitic (Figure 4d), locally holohyaline or spherulitic. Phenocrysts, up to $5 \mathrm{~mm}$ long, are of plagioclase $\left(\mathrm{An}_{40-50}\right)$ or altered clinopyroxene. 


\subsection{Basaltic Lava Flows}

[26] Stacked lava flows of basalt or basaltic andesite form a cover to the entire edifice (Figure 2) [Zollner and Amos, 1973; Holmberg, 1975]. The thickness of each flow is no more than a few meters and surprisingly uniform over large distances. Seven basaltic lava flows were selected for dating (see Table 1). The texture is porphyritic, coarsely vesicular, and banded. The groundmass is microlitic to trachytic (Figure 4e). Phenocrysts (less than $20 \mathrm{vol} \%$ ) are 5 to $8 \mathrm{~mm}$ long. They are mostly of plagioclase $\left(\mathrm{An}_{40-70}\right)$ or olivine, with minor clinopyroxene.

[27] Zollner and Amos [1973] and Holmberg [1975] grouped the basalts into various formations, according to field relationships. The oldest (Basalto III, Pleistocene) is mostly on the northern and western flanks of the volcano (Los Barros and Cerro Wayle areas), and locally crops out on the eastern flank (Los Chihuidos de Tril; Figure 2). The Basalto IV formation crops out locally on the northern and eastern flanks. Forming the main cones of Tromen, Cerro Negro del Tromen and Cerro Wayle are flows of the Basalto $\mathrm{V}$ formation. They overlie andesite domes of the Tilhué formation (Figure 5) and some eroded E-W dikes (in the upper Arroyo Blanco valley). Near the summit of Tromen are Holocene basalts and basaltic andesites of the Basalto VI and Basalto VII formations [Llambias et al., 1982].

[28] The basalts appear to be very homogeneous, both in the field and under the microscope. From petrological features alone, it is difficult to assign any one sample to a given formation. Also it is difficult to correlate the formations on the basis of field relationships.

\subsection{Conglomerate}

[29] On the eastern flank of Tromen, conglomerate of the Pichichacaico formation crops out at altitudes of 1500 to $1900 \mathrm{~m}$, over a distance of about $20 \mathrm{~km}$ (Figure 2). Holmberg [1975] considered it to be Pleistocene (older than the Basalto III formation, but younger than the Tilhué formation). It contains rounded pebbles, about $10 \mathrm{~cm}$ in diameter, and angular fragments, mostly of basaltic andesite [Holmberg, 1975]. The matrix is a sand of the same composition. The pebbles are of two distinct kinds, according to phenocryst length ( $5 \mathrm{~mm}$ for TR01; $2 \mathrm{~mm}$ for TR02; Table 1). Both have a porphyritic vesicular texture, a microlitic groundmass (Figure 4f) and phenocrysts of plagioclase $\left(\mathrm{An}_{30-40}\right)$ and clinopyroxene. In the field, conglomerate of the Pichichacaico formation appears to be overlain by lava flows of the Basalto IV formation (Figure 2a).

[30] Also on the eastern flank of Tromen, the Agua Carmonina formation is a conglomerate, containing upper layers of ash and travertine, whereas the Arroyo Huecú formation is a conglomerate only. All contain rounded pebbles, from $10 \mathrm{~cm}$ to $1 \mathrm{~m}$ in diameter, basaltic sand and lapilli [Holmberg, 1975]. Because of their greater variety of pebbles, the Agua Carmonina and Arroyo Huecú formations are thought to be younger than the Pichichacaico formation (Figure 2) [Holmberg, 1975].
[31] On the eastern flank of the volcano, another conglomerate, a few meters thick, has an upper crust of calcrete ("tosca") and is unconformable upon underlying strata [Holmberg, 1975]. It contains rounded blocks of basalt and andesite, up to $50 \mathrm{~cm}$ wide. We were not able to correlate this material with any other conglomerate in the area.

[32] On the western flank of Tromen (Arroyo Blanco), a thick conglomerate fills paleovalleys in underlying ignimbrite. It contains pebbles of basalt and andesite, up to a few tens of $\mathrm{cm}$ wide. In the lower part of the valley, the conglomerate rests directly on Mesozoic strata. It also covers andesite domes (El Paso) and E-W dikes. Apparently overlying it are lava flows of the Basalto $\mathrm{V}$ formation. We cannot correlate this conglomerate with the one on the eastern flank of the volcano.

[33] Zollner and Amos [1973] suggested that some, if not all, of these conglomeratic deposits formed during periods of Pleistocene glaciation. Indeed some of the main valleys on Tromen appear to be of glacial origin.

\section{4. $\mathrm{New}{ }^{39} \mathrm{Ar}^{-40} \mathrm{Ar}$ Ages}

\subsection{Sampling}

[34] Thirty-one samples, from the main volcanic formations or from blocks in conglomerate, were selected for dating (Table 1).

[35] The samples were mainly from lava flows, volcanic domes and dikes. Exceptions were (1) a fine-grained lithic block (TIL04) from a pyroclastic deposit near one of the domes of Cerro Tilhué (see "Products of Tromen"), (2) an obsidian fragment from an ignimbrite (CM05-01) and (3) two volcanic blocks from conglomerate of the Pichichacaico formation (TR01 and TR02; Table 1). Weathered and hydrothermally altered rocks were discarded. We did not sample the youngest basaltic lava flows (Basalto VI and Basalto VII formations) or the oldest ones (Basalto I and II, which did not obviously erupt from Tromen).

\subsection{Analytical Procedure}

[36] Samples were analyzed with an ${ }^{39} \mathrm{Ar}-{ }^{40} \mathrm{Ar}$ laser probe $\left(\mathrm{CO}_{2}\right.$ Synrad $\left.^{\mathrm{B}}\right)$. The analyses were mostly on single whole rock fragments of basalt or andesite (Table 1). Others were on biotite from andesites, dacites and rhyolites and an obsidian pyroclast from the ignimbrite.

[37] Whole rock fragments and minerals were carefully handpicked under a binocular microscope from crushed rocks $(0.3-2 \mathrm{~mm}$ fraction). The samples were wrapped in A1 foil to form packets $(11 \mathrm{~mm} \times 11 \mathrm{~mm} \times 0.5 \mathrm{~mm})$. These packets were stacked up to form a pile, within which packets of flux monitors were inserted every 8 to 10 samples. The stack, put in an irradiation can, was irradiated for 5 hours at the McMaster reactor (Hamilton, Canada) with a total flux of $6.4 \times 10^{17}$ radioactive shocks per square centimeter. The irradiation standard was the Alder Creek Rhyolite sanidine, ACs-2 (1.194 Ma according to Renne et al. [1998]). The sample arrangement allowed us to monitor the flux gradient with a precision of $\pm 0.2 \%$. 


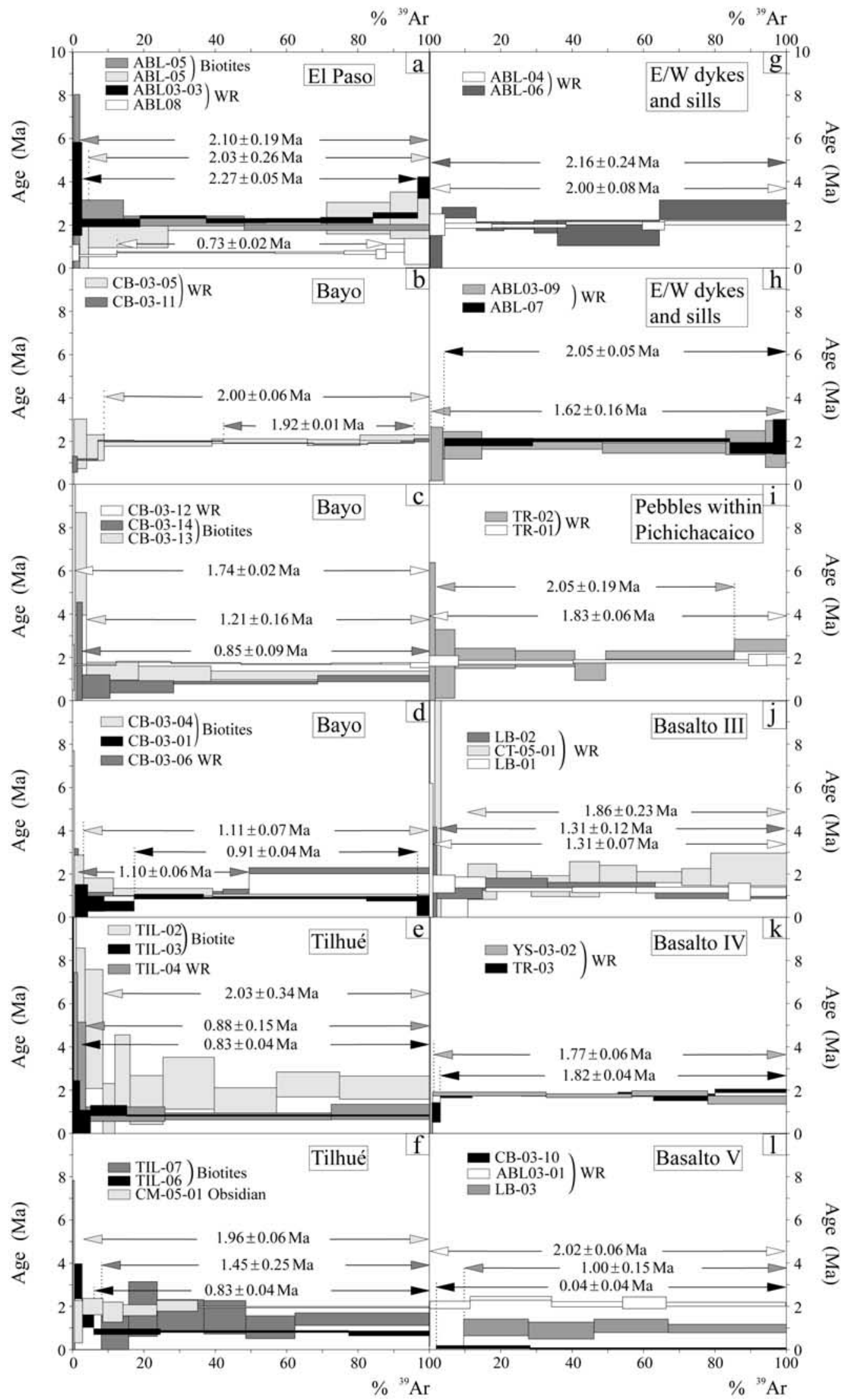

Figure 6

11 of 24 
[38] The step-heating experimental procedure has been described in detail [Ruffet et al., 1991, 1995]. Blanks are performed routinely each first or third run, and are subtracted from the subsequent sample gas fractions. Analyses are performed on a Map2 $15^{\mathrm{E}}$ mass spectrometer.

[39] To define a plateau age (PA), a minimum of three consecutive steps are required, corresponding to a minimum of $70 \%$ of the total ${ }^{39} \mathrm{Ar}_{\mathrm{K}}$ released, and the individual fraction ages should agree to within $1 \sigma$ or $2 \sigma$ with the integrated age of the plateau segment. Plateau ages (PA) have been calculated at $1 \sigma$ or $2 \sigma$ level, according to quality of analysis (see Table 1). A pseudoplateau age, with less than $70 \%$ of ${ }^{39} \mathrm{Ar}_{\mathrm{K}}$ released, was defined for one sample (CB03-11; Table 1 and Figure 6). The ${ }^{39} \mathrm{Ar}-{ }^{40} \mathrm{Ar}$ results in Table 1 are displayed at the $1 \sigma$ level and the plateau ages are shown at the $1 \sigma$ level (Figures 6 and 7).

\subsection{Results}

[40] All ages except one are plateau ages (Table 1 and Figure 6). Sample CB03-11 gave a pseudoplateau with less than $70 \%$ of ${ }^{39} \mathrm{Ar}_{\mathrm{K}}$ released. Oldest $(2.27 \pm 0.10 \mathrm{Ma}$, Table 1$)$ was an andesite from the domes at El Paso.

[41] The ages of the andesite domes (Tilhué formation) range from $2.27 \pm 0.10 \mathrm{Ma}$ to $0.75 \pm 0.05 \mathrm{Ma}$ (Table 1 and Figure 7) and form two groups: an early one, ranging from about $2.27 \pm 0.10 \mathrm{Ma}$ to $1.74 \pm 0.02 \mathrm{Ma}$, and a later one, ranging from about $1.45 \pm 0.25 \mathrm{Ma}$ to $0.75 \pm 0.05 \mathrm{Ma}$ (Figure 7). The early group includes most of the domes at El Paso (ABL05, ABL03-03), a few domes (CB03-05) and underlying andesite lava flows (CB03-11 and CB03-12) at Cerro Bayo, and one dome at Cerro Tilhué (TIL02). The later group includes most of the domes at Cerro Tilhué and Cerro Bayo, and one dome at El Paso (ABL08; Table 1, Figure 7).

[42] Among the pyroclastic deposits, the ignimbrite (sample CM05-01) gave an age of $1.96 \pm 0.06$ Ma. From Cerro Tilhué, one of the samples (TIL04) is a fine-grained lithic block from a pyroclastic deposit. It gave a relatively young age $(0.88 \pm 0.15 \mathrm{Ma}$; Table 1$)$. It may have originated in a shallow level intrusive body, subcontemporaneous with volcanic domes at Cerro Tilhué, but it does not correlate with any surface lavas.

[43] The age of the large volcanic neck east of Tromen (Chihuido de Tril) is $1.86 \pm 0.23 \mathrm{Ma}$. The measured age of the andesite sills in the Arroyo Blanco is $2.16 \pm 0.24 \mathrm{Ma}$ (ABL06; Table 1). These sills are crosscut by E-W dikes, which indeed are contemporaneous to younger (2.05 \pm $0.05 \mathrm{Ma}$ to $1.62 \pm 0.16 \mathrm{Ma}$; Table 1; Figure 7).

[44] The ages for the basalt flows range from $2.02 \pm 0.06 \mathrm{Ma}$ to $0.04 \pm 0.04 \mathrm{Ma}$. Those for the Basalto III formation cluster around 1.3 Ma (Table 1). For the Basalto IV formation, which is supposedly younger, the ages are in fact older $(1.82 \pm 0.04 \mathrm{Ma}$ for TR03 and $1.77 \pm 0.06 \mathrm{Ma}$ for
YS03-02; Table 1). Finally, the ages for the Basalto V formation range from $2.02 \pm 0.06 \mathrm{Ma}$ (ABL03-01; Table 1) to $0.04 \pm 0.04 \mathrm{Ma}$ (CB03-10; Table 1). Because the samples of Basalto III and Basalto IV were from geographically restricted areas (around Los Barros and Las Yeseras, respectively), it is not surprising that their ages cluster. In contrast, samples of the Basalto $\mathrm{V}$ formation came from more widespread areas (see Table 1), and this probably explains the wider range of ages. Although the error range on sample CB03-10 is large $(0.04 \pm 0.04 \mathrm{Ma})$, this analysis unambiguously indicates that the sampled lava flow is very young. As far as we know, this age is the youngest obtained for Tromen lava. It is consistent with our geological observations. In the field, the lava flow overlies the Tilhué formation, but its outcrop area is too small to be visible at the scale of our map (Figure 2a).

[45] The two kinds of pebbles from conglomerate of the Pichichacaico formation gave ages of $2.05 \pm 0.19$ (TR02) and $1.83 \pm 0.06 \mathrm{Ma}$ (TR01; Table 1).

\subsection{Stratigraphic Implications}

[46] The oldest rocks that we dated on Tromen were andesitic to dacitic domes of the Tilhué formation, especially at El Paso $(2.27 \pm 0.10 \mathrm{Ma})$. Some early andesitic domes also formed at Cerro Tilhué and Cerro Bayo (Table 1 and Figure 7). However, in general our ages show that the Tilhué formation is strongly diachronous, spanning the period between $2.27 \pm 0.10 \mathrm{Ma}$ and $0.75 \pm 0.05 \mathrm{Ma}$. Kay et al. [2006a, p. 53, sample TDR-16] obtained an Ar/Ar age of $4.0 \pm 0.4 \mathrm{Ma}$ on biotite from a Cerro Bayo rhyolite. The age spectrum is typical of chloritized biotite, so that the calculated plateau age $(4.0 \pm 0.4 \mathrm{Ma})$ may overestimate the true age of the mineral (as by Cheilletz et al. [1999]). Nevertheless, the result could indicate that activity on Tromen started before $2.27 \mathrm{Ma}$.

[47] At El Paso, Cerro Tilhué, and Cerro Bayo, the youngest domes are younger than most of the basalt flows, whereas the oldest are contemporaneous with the E-W dikes, the pebbles within the Pichichacaico conglomerate, and the early lava flows (Table 1 and Figure 7). Thus, in contrast to Zollner and Amos [1973] and Holmberg [1975], we argue that silica-rich products were not restricted to the early stages of activity on Tromen. In addition the age of the ignimbrite at $1.96 \pm 0.06 \mathrm{Ma}$, similar to those of some of the domes, indicates that some ignimbrites covering the area might result from Tromen, as suggested also by Kay et al. [2006a].

[48] Our ages also indicate that the domes of the Tilhué formation extruded sequentially (Table 1). At El Paso, early domes lie upon Mesozoic strata at $2600 \mathrm{~m}$, whereas a later one is near the top of the volcano at about $3150 \mathrm{~m}$. At Cerro Bayo, early domes are at the bottom of the Arroyo Chacaico (Figure 3) at about $1800 \mathrm{~m}$, whereas a later group is

Figure 6. The ${ }^{39} \mathrm{Ar}^{40} \mathrm{Ar}$ age spectra of 31 samples of volcanic rocks from Tromen. The error bars for each temperature step are at the $1 \sigma$ level and do not include errors in the $\mathbf{J}$ values. The errors in the $\mathbf{J}$ values are included in the plateau age calculations. 


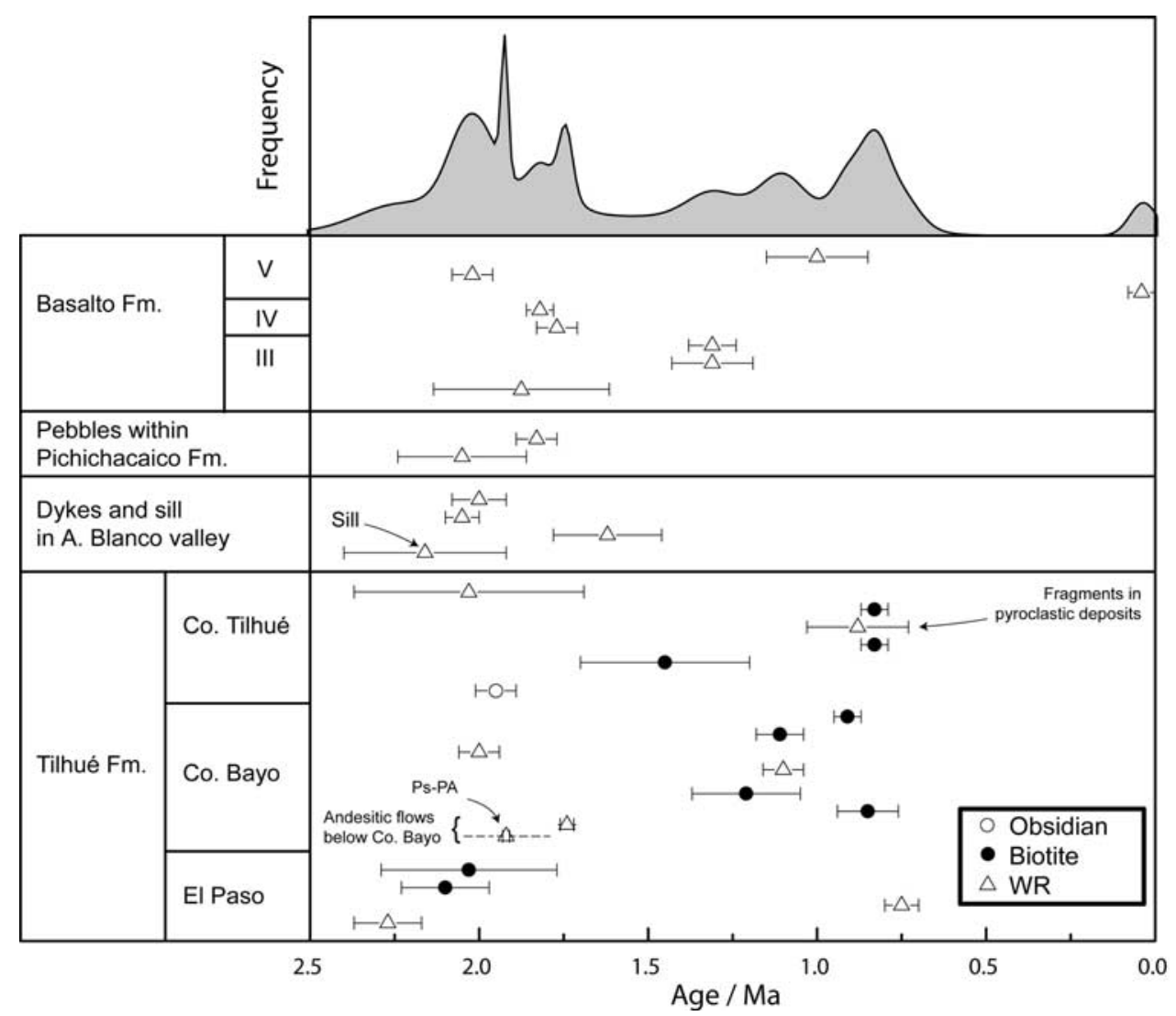

Figure 7. The ${ }^{39} \mathrm{Ar}-{ }^{40} \mathrm{Ar}$ plateau ages (with errors at the $1 \sigma$ level) of samples from various geological formations on Tromen. Samples of Tilhué formation are in three groups (from El Paso, Cerro Bayo and Cerro Tilhué). The histogram of plateau ages has been calculated using errors at the $1 \sigma$ level. Ps-Pa denotes the pseudoplateau age (Table 1).

between 2050 and $2200 \mathrm{~m}$. At Cerro Tilhué, the earliest dome is at the base of the andesite series at $2031 \mathrm{~m}$, whereas later ones are above $2150 \mathrm{~m}$. Thus, in each area, younger domes stand above older ones, as might be expected for sequential extrusion. However, a few samples from young domes were collected at lower altitudes than those from older domes (examples CB03-14 and CB03-04, Table 1).

[49] For the basalt flows, our ages uphold previous deductions from local field relationships. On the eastern flank of Tromen, samples of the Basalto IV formation are effectively older than the one sample of the Basalto $\mathrm{V}$ formation (Table 1), upholding the relationships of Holmberg [1975]. On the western flank, except for ABL03-01, samples of the Basalto III formation are indeed older than those of the Basalto $\mathrm{V}$ formation (Table 1), confirming the observations of Zollner and Amos [1973]. However, from one flank to another, the formation ages do not match. This discrepancy probably illustrates the difficulty of correlating over wide areas, especially when the rocks are petrologically very similar.

[50] The ages of the conglomeratic deposits are poorly constrained. Those for pebbles in the Pichichacaico conglomerate are late Pliocene, hence somewhat older than inferred by Holmberg [1975] for the conglomerate itself, but older indeed than the Basalto IV formation.

[51] In summary, our ages show that basaltic and more siliceous products erupted almost simultaneously from Tromen, throughout its $2 \mathrm{Ma}$ of activity.

\section{Structure of Tromen}

[52] Tromen is at the northern end of the Agrio fold-andtrust belt (Figure 1). The Mesozoic sedimentary substrate of the volcano is intensely deformed. The main tectonic structure in the area is the eastward verging Tromen thrust, at the eastern foot of the volcano (Figures 2 and 8). According to seismic data, this thrust is deep-seated, involving Paleozoic to Triassic basement [Kozlowski et al., 1996; Zapata et al., 1999]. Jurassic evaporites of the Auquilco formation crop out in its hanging wall, in the overturned Las Yeseras anticline (Figures 2 and 8) [Holmberg, 1975; Kozlowski et al., 1996]. In map view, the Tromen thrust is strongly arcuate (Figure 8). It may have formed that way, under the weight of Tromen [Branquet and van Wyk de Vries, 2001; Marques and Cobbold, 2002], or it could be inherited from basement structures, such as 


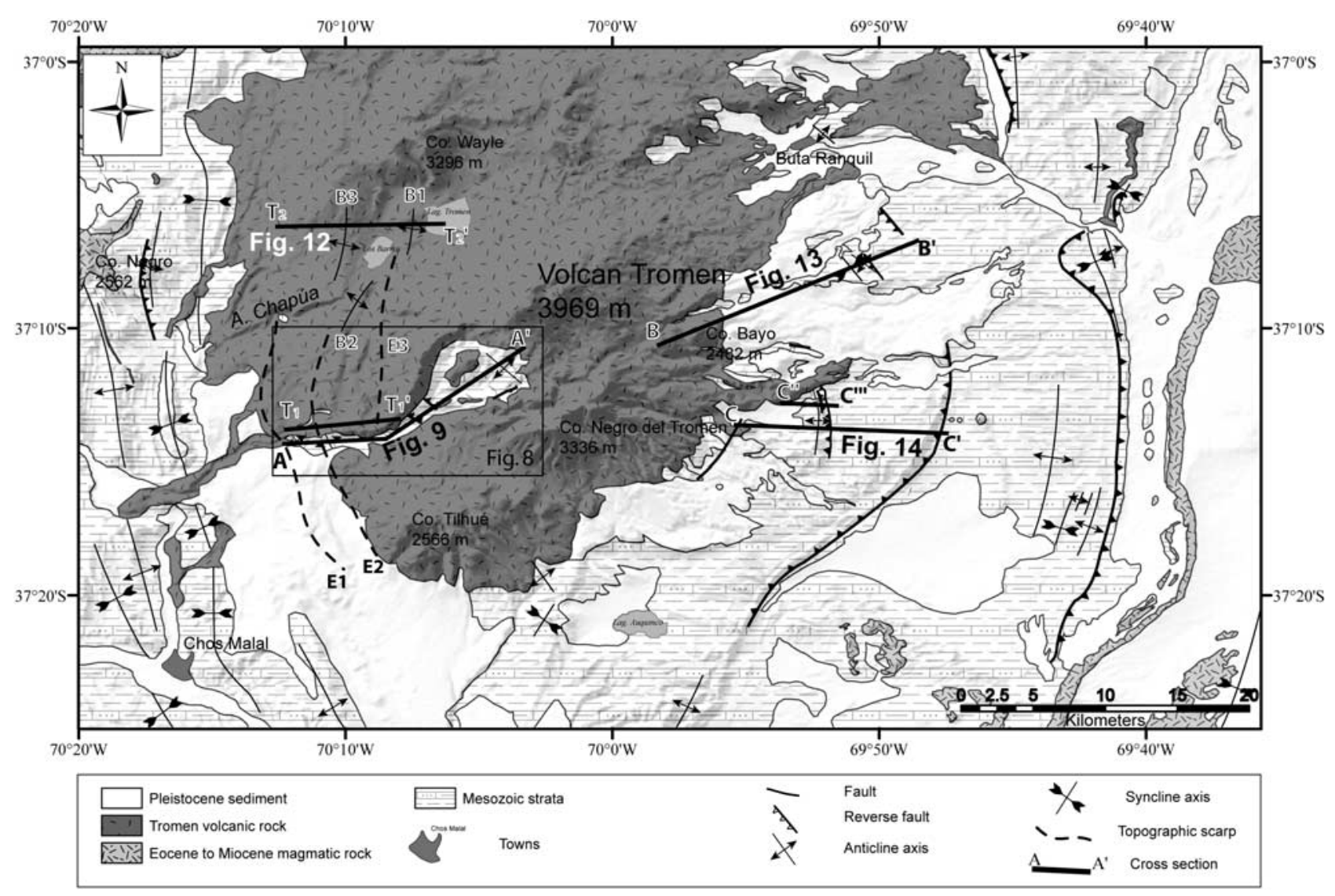

Figure 8. Structural map of Tromen. Folds and thrusts trend mainly N-S and curve around base of volcano. Black lines indicate sections (Figures 9, 11, 13, and 14). Dashed lines are traces of topographic escarpments (E1, E2, and E3). Anticlines in basaltic lavas are labeled (B1, B2, and B3).

Triassic or Jurassic normal faults [Manceda and Figueroa, 1995; Vergani et al., 1995; Zapata et al., 1999]. Below we list new field observations from the western, northwestern, northeastern, and eastern flanks of Tromen, where erosion has provided the best views of structural relationships (Figure 8).

\subsection{Western Flank}

[53] Arroyo Blanco is a deeply incised valley on the western flank of Tromen. It provides an almost continuous section through deformed Mesozoic strata and their thin volcanic cover (Figure 9, $\mathrm{AA}^{\prime}$ ).

[54] In the western part of the profile, a conglomerate is unconformable upon an eroded westward verging anticline in the Agrio formation (anticline A1, Figure 9). This anticline coincides in position and trend with a topographic escarpment (E1, Figure 9), which can be traced to north and south (Figure 8). A second anticline (A2, Figure 9) is partly masked by pyroclastic deposits. Again, it coincides with a topographic escarpment (E2, Figure 9) that continues to north and south (Figure 8). The pyroclastic deposits are unconformable upon the Mesozoic strata, filling paleovalleys. There are two families of subvertical joints in the ignimbrites (stereogram, Figure 9). Such preferred orienta- tions are unlikely to result from cooling. Instead, the acute bisector probably indicates E/W shortening. The ignimbrites are unconformably overlain by thick conglomerate that also fills paleovalleys (Figure 9).

[55] Further east, oil seeps through a more open anticline (Figure 9) [Cruz et al., 1996]. On its eastern flank are three westward verging reverse faults (F1, F2 and F3, Figure 9). These coincide with a third topographic escarpment (E3, Figure 9) that can be traced to the north (Figure 8), this time in lava flows of the Basalto $\mathrm{V}$ formation (Figure 9). The flow units become steeper at the escarpment, but do not change in thickness, and this argues for folding after consolidation, as a result of reverse faulting at depth.

[56] Near the eastern end of the section is a large eastward verging anticline (A3, Figure 9). On its western flank, the Vaca Muerta to Agrio formations are monoclinal. A reverse fault in the Vaca Muerta formation carries striations that are compatible with E-W shortening (stereogram, Figure 9). Andesite sills lie within the Mulichinco and Vaca Muerta formations. To the eastern end of the section, andesite domes of the Tilhué formation are unconformable upon eroded strata of the Vaca Muerta formation (Figure 9).

[57] Subvertical E-W dikes crosscut the sills, the Mesozoic strata, and even the domes (Figure 5). Some of the 
a

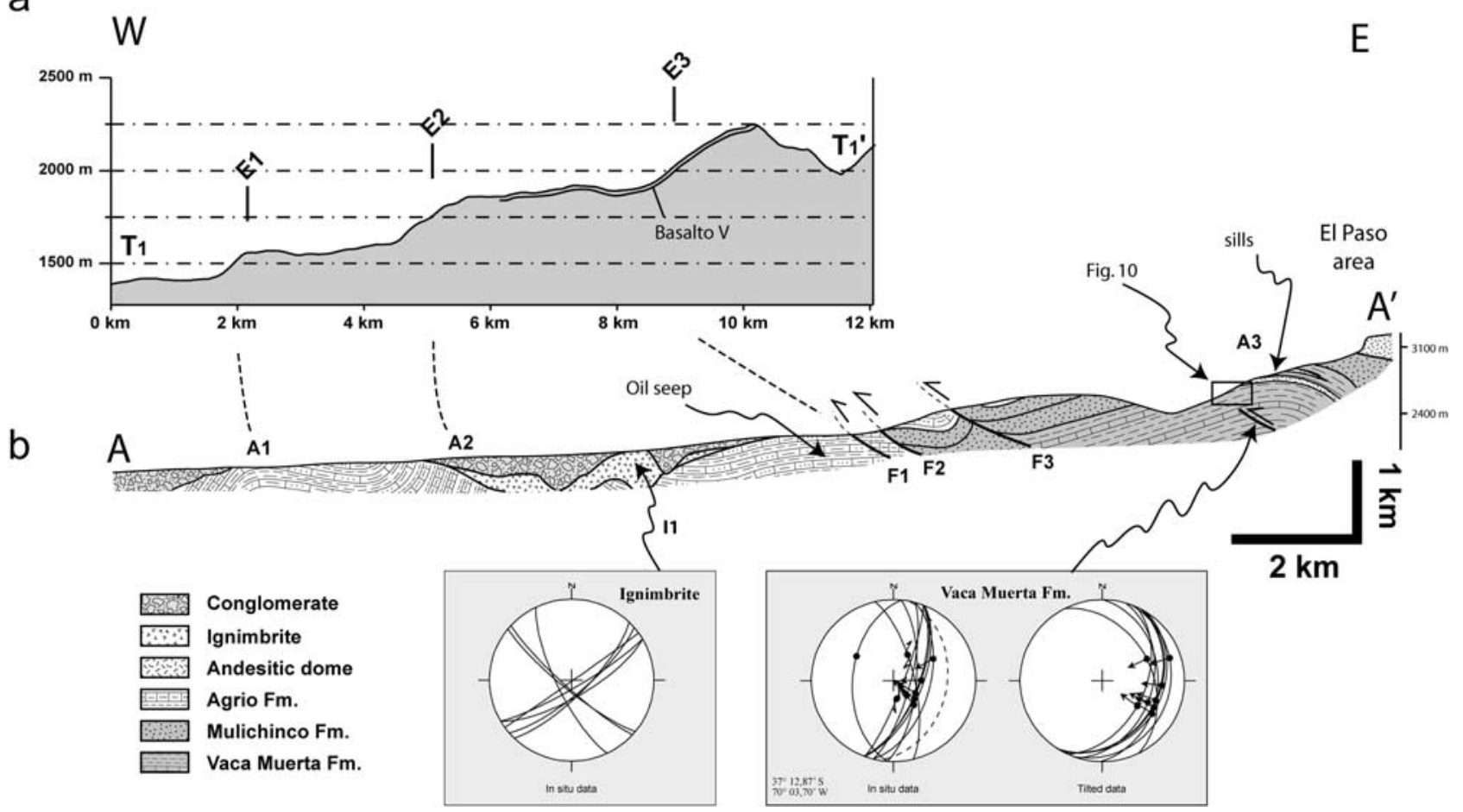

Figure 9. Structures on western flank of Tromen. (a) Topographic cross section along northern edge of Arroyo Blanco. For location, see Figure 8. Notice three topographic escarpments (E1, E2, and E3). Vertical scale is exaggerated. (b) Geological cross section along Arroyo Blanco. For section line, see Figure 8. Vertical scale is 1.2 times horizonal scale. Stereograms (lower hemisphere, from programs of Angelier [1984, 1990]) show joints in ignimbrite and fault slip data in Vaca Muerta formation. Solid lines are for faults and joint planes, dashed lines are for bedding, dots are for striations, and arrows indicate motion of footwall. For ignimbrite, two families of vertical joints, if they are shear joints, are compatible with E-W shortening. For Vaca Muerta formation, stereograms show data in situ (left) and after tilting of bedding to horizontal (right). The latter are compatible with E-W shortening. Notice that anticlines (A1, and A2) and reverse faults (F1, F2, and F3) correlate with topographic escarpments (E1, E2, and E3).

Outcrop of pyroclastic deposits (I1) is located on Figure 5a.

dikes are offset up to $20 \mathrm{~m}$ across N-S striking faults, which have reverse and strike-slip components of slip, giving E-W shortening (Figure 10). The easternmost outcrops of Mesozoic strata reach an altitude of $3000 \mathrm{~m}$ (Figure 9), some $2000 \mathrm{~m}$ above the foot of the volcano and $1000 \mathrm{~m}$ below the summit. Thus Tromen has a relatively thin volcanic cover, above a much thicker substrate of deformed sedimentary rock.

[58] Some kilometers north of the Arroyo Blanco valley, pyroclastic deposits, including ignimbrite, crop out along much of the incised valley of Arroyo Chapúa (Figures 2 and 5). They are unconformable on steeply dipping beds of the Agrio formation in the core of a fault-related anticline (Figures 2a and 8). The uppermost layers of redeposited ash (white, Figure 11a) appear to onlap the anticline. In the hinge, a striated fault, left-lateral and reverse, is compatible with NW-SE shortening.

[59] These exposures are at the northern end of topographic escarpment E1 (Figures 5 and 8). Between Arroyo
Blanco and Arroyo Chapúa, the escarpment is continuous and has an arcuate trace.

\subsection{Northwestern Flank}

[60] Between Los Barros and Laguna del Tromen, a volcanic plateau is overlain by a series of thin basaltic flows (Basalto III and Basalto V formations; Figures 2 and 12). In this area, three topographic ridges trend NNE-SSW (B1, B2 and B3, Figure 8). These are anticlinal hinges in the lava flows. The flow units maintain nearly constant thicknesses around the hinges and they have dips of $15^{\circ}$ or more on the flanks. Flattened vesicles lie parallel to the layering and have been folded as well (Figure 12). Locally, the long axes of the vesicles, marking a flow direction, are oblique to the current topographic slope and also to the current dip directions. We infer that the folds formed after flow and cooling of the lava. Because of their elongate shapes, the anticlines are unlikely to be due to magmatic intrusion. Because they appear to prolong the topographic escarpments (E1, E2 and E3, Figure 8), which themselves overlie 


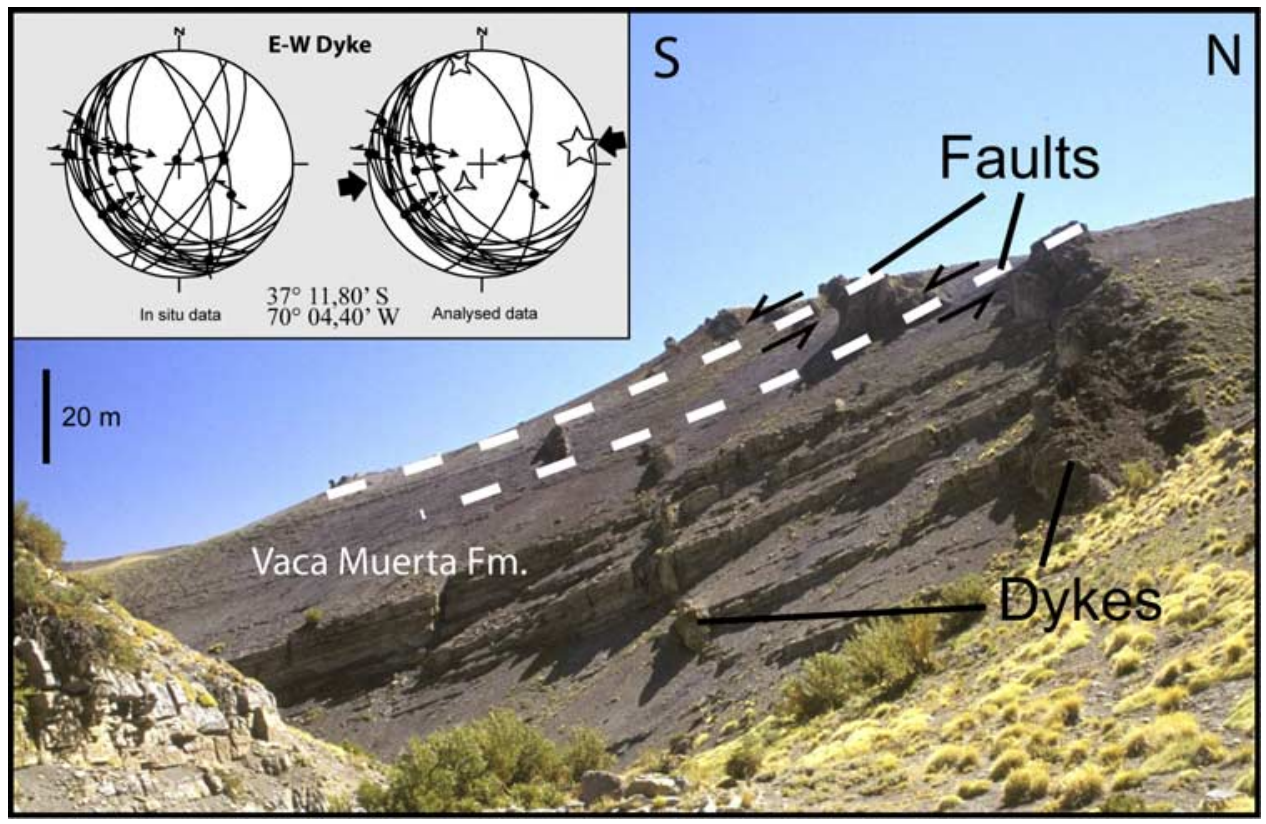

Figure 10. Dikes in upper reaches of Arroyo Blanco. For location, see Figures 5 and 9. View is to west. Dikes are offset by two major faults. Stereograms (inset, lower hemisphere) show minor faults. Solid lines are for faults and joint planes, dots are for striations, and arrows indicate motion of footwall. In situ data (left) are as measured. Analyzed data (right) yield acceptable solution for stress tensor (from programs of Angelier [1984, 1990]). Calculated axes of principal stress (five-, four- and three-pointed stars) are for $\sigma_{1}$ (greatest), $\sigma_{2}$ (intermediate) and $\sigma_{3}$ (smallest). Data are compatible with E-W shortening (black arrows).

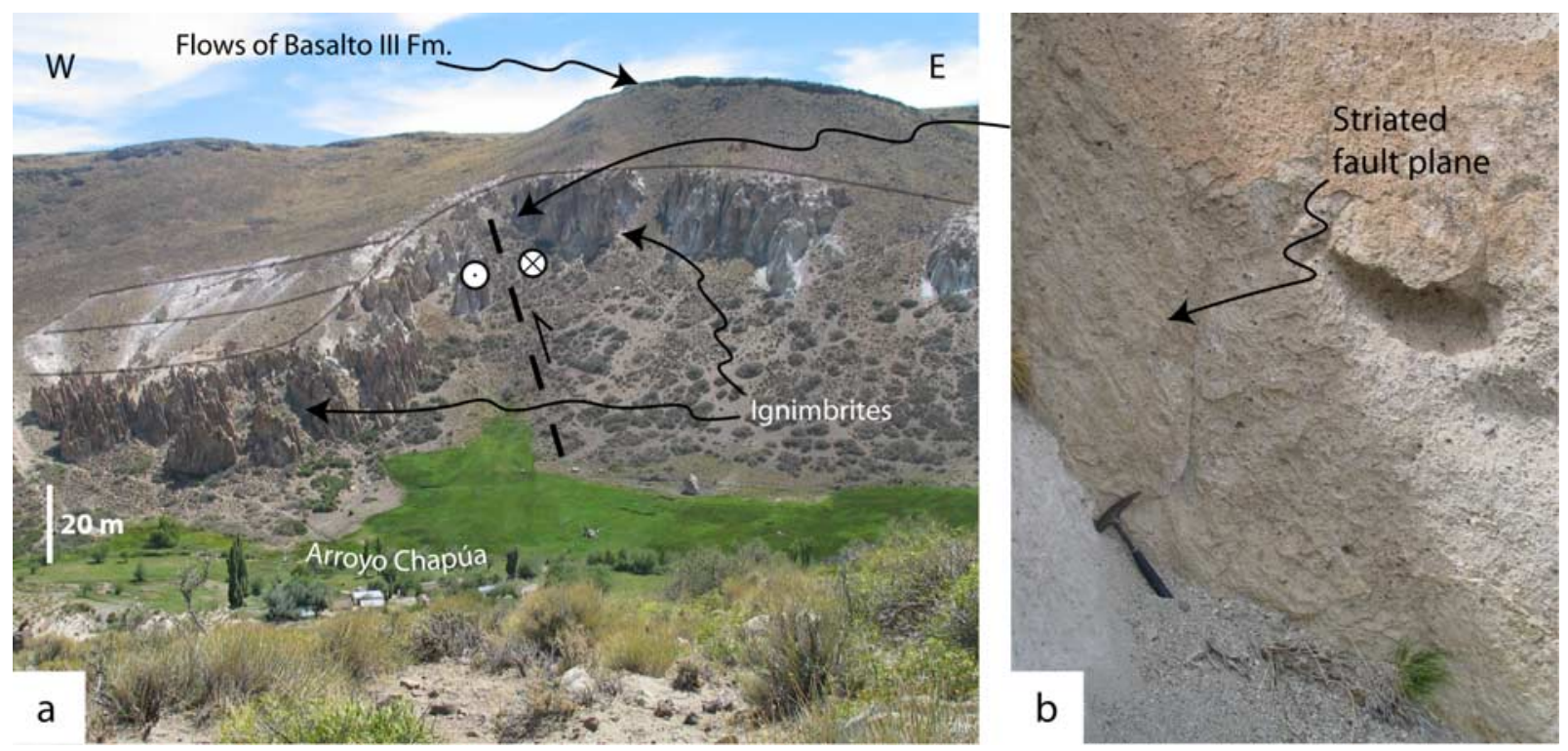

Figure 11. (a) Fault-related anticline in pyroclastic deposits, Arroyo Chapúa. View is to north. For location, see Figure 5. Upper layers of redeposited ash (white) onlap folded ignimbrite (forming cliffs). Fault (dashed trace) offsets base of ignimbrite and underlying strata of Agrio formation (foreground). (b) Close-up view of fault plane in ignimbrite (located in Figure 11a by arrow). Fault surface dips at $87^{\circ}$ toward N112 ${ }^{\circ}$. Striation plunges $66^{\circ}$ to south. Sense of slip is left lateral, reverse. This fault is compatible with NW-SE shortening. 

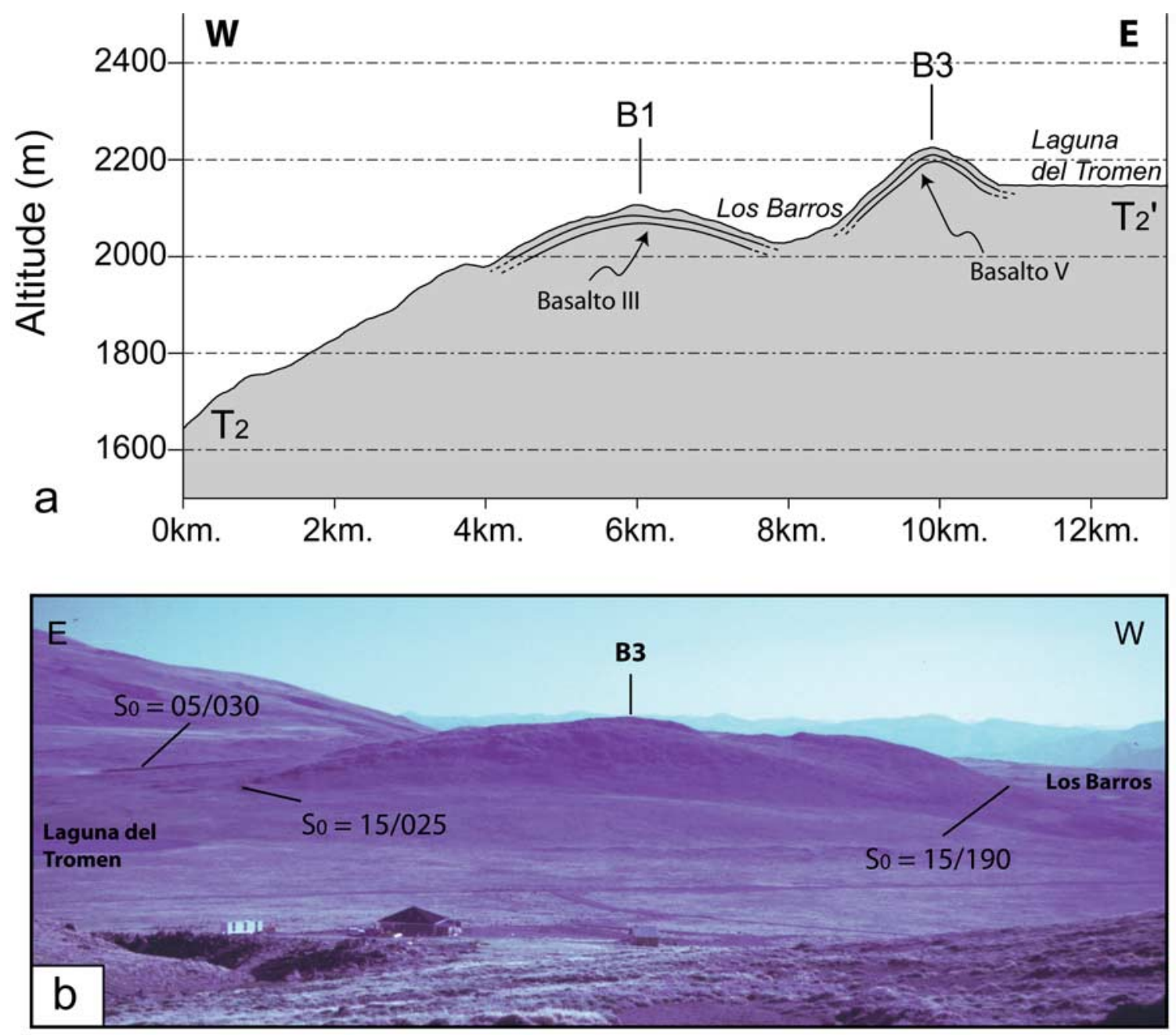

Figure 12. (a) Topographic cross section, Los Barros to Laguna del Tromen. View is to south. For location, see Figure 8. Lava flows of Basalto III and Basalto V formations control free surface. Topographic highs are anticlines (B1 and B3). Vertical scale is 6.4 times horizontal scale. (b) Panoramic view of anticline B3 between Laguna del Tromen and Los Barros. $\mathrm{S}_{0}$ indicates flow banding of lava.

reverse faults in the substrate, we infer that the anticlines are due to ESE-WNW shortening. Because the folds are gentle, small-scale fracturing should be enough to accommodate the small amounts of bending in individual consolidated layers, and flexural slip may be the mechanism of folding at the scale of the lava pile.

\subsection{Northeastern Flank}

[61] To the east of Cerro Bayo dome, sandstones of the Mulichinco formation crop out widely (Figures 2 and 13), whereas the underlying black shale of the Vaca Muerta formation is only exposed in valleys. The bedding dips almost uniformly at $5-10^{\circ}$ to the NE, except across open folds and reverse faults trending NNW-SSE (Figures 8 and 13). Holmberg [1975] reported outcrops of the Huitrín formation in the area. Although his map indicates a hiatus between the Mulichinco and Huitrín formations, we did not observe one. Instead, we found the Vaca Muerta formation. Upon it and the Mulichinco formation, Pleistocene sediment of the
Huecú formation forms a thin unconformable layer (Figure 13), in which two families of joints define a dihedral angle that is compatible with E-W shortening (stereogram, Figure 13).

[62] Along the western part of the cross section $\left(\mathrm{BB}^{\prime}\right.$, Figure 13), in the Arroyo Chacaico (located in Figure 2a), black shale of the Vaca Muerta formation dips gently to the $\mathrm{NE}$, beneath the volcanic domes. Further west, alternating conglomeratic units and andesite lavas of the Tilhué formation dip at about $20^{\circ} \mathrm{W}$ and are probably unconformable upon Mesozoic strata. The inward dip is rather unexpected for the flank of a volcano. The andesitic domes of Cerro Bayo are unconformable upon this series (Figure 13). We therefore suspect that major tectonic or erosional events occurred during accumulation of the Tilhué formation.

\subsection{Eastern Flank}

[63] At Las Yeseras (gypsum quarries), evaporites of the Auquilco formation are in the core of an exhumed anticline, 


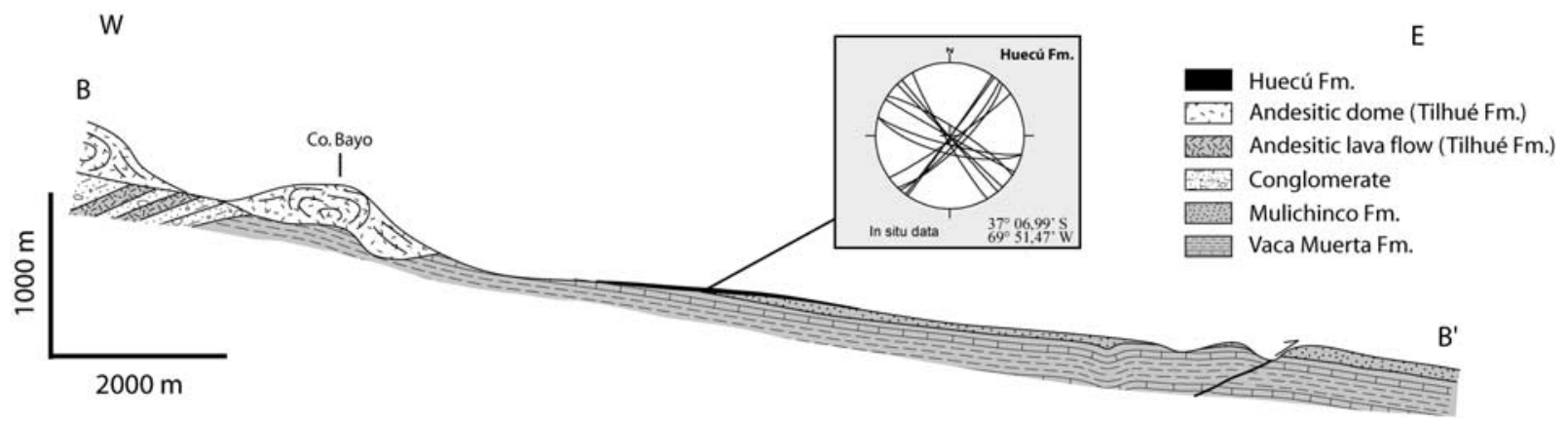

Figure 13. Cross section at Cerro Bayo, NE flank of Tromen. For location, see Figure 8. Stereogram (lower hemisphere) represents two families of joints in Huecu formation. They are compatible with E-W shortening. Vertical scale is twice horizontal scale.

in the hanging wall of the eastward verging Tromen thrust (Figure 2) [Holmberg, 1975; Kozlowski et al., 1996]. This thrust is blind. At the surface is an asymmetric anticline, whereas at depth the thrust involves Paleozoic basement [Kozlowski et al., 1996; Zapata et al., 1999]. Across the plateau of Pampa Tril, Mesozoic strata of the Agrio and Mulichinco formations dip very gently to the west (eastern end of section $\mathrm{CC}^{\prime}$, Figures 8 and 14). In the hanging wall of the Tromen thrust, strata of the Agrio to Tordillo formations dip steeply to the east, and are locally overturned. Fault slip data and joints within the Mulichinco formation indicate E-W shortening (Figure 14).

[64] For more than $10 \mathrm{~km}$ across Las Yeseras, the Auquilco formation consists mainly of gypsum, some $400 \mathrm{~m}$ thick [Holmberg, 1975]. However, it has one internal layer of limestone, $10 \mathrm{~m}$ thick (Calico member, Figures 2 and 14). Between Las Yeseras and La Vega de la Totora, the Calico member forms an asymmetric anticline. In its core is an older limestone (Manga member of the Lotena formation). To the north, the anticline ends against the eastward verging Yesera thrust. Between the Yesera thrust and a local back thrust is a pop-up, which consists mainly of breccia. Angular blocks, tens of meters wide, derive from material of the Auquilco formation and the Lotena group (Figure 14). We interpret this breccia as a tectonic melange. Notice that to the east of the Yesera thrust, sandstone of the Tordillo formation (Figures 2a and 14) and locally black shale of the Vaca Muerta formation crop out. They fill the core of a smooth syncline (Figure 14).

[65] Further west, bedding in the Lotena group forms the asymmetric Totora anticline (Figure 14). Joints and striated faults in sandstones of the Lotena formation indicate E-W shortening. On the western flank of the anticline, the stratigraphic succession is complete, from the Lotena group to the Vaca Muerta formation.

[66] Toward the western end of the cross section, conglomerate of the Pichichacaico formation is unconformable upon the Vaca Muerta, Tordillo and Auquilco formations, filling a paleovalley (Figure 14). The conglomerate hosts two families of vertical fractures, which crosscut the pebbles. The fractures strike at about $\mathrm{N}^{\circ} 0^{\circ}$ and $\mathrm{N} 120^{\circ}$, defining a dihedral angle that is compatible with E-W shortening.
Both pebbles and matrix show signs of hydrothermal alteration.

[67] To the west of the conglomerate is another breccia, containing blocks, up to $10 \mathrm{~m}$ wide, of material from the Auquilco, Tordillo and Vaca Muerta formations (Figure 14). We could not see the nature of the contact between breccia and conglomerate. However, one of the blocks in the breccia derives from a conglomerate, which is very similar to the Pichichacaico formation (photo, Figure 14). We interpret the breccia to be a tectonic melange in a major thrust zone (Totora thrust, Figure 14).

\section{Implications for Tromen}

[68] According to our ${ }^{39} \mathrm{Ar}-{ }^{40} \mathrm{Ar}$ data (Figure 7), the magmatic products and conglomerates of Tromen are of late Pliocene to Holocene age. In addition, some of the geological formations, as defined by Zollner and Amos [1973] and Holmberg [1975], are composite, while others are diachronous. Rather than set up a new classification, we will describe the growth and structure of Tromen, emphasizing the close relationships between magmatism and deformation.

\subsection{Growth of Tromen}

[69] The ${ }^{39} \mathrm{Ar}-{ }^{40} \mathrm{Ar}$ ages for Tromen are consistent with those of other back-arc volcanoes in the Neuquén basin, such as Auca Mahuida [Rossello et al., 2002; Kay et al., 2006a] and Payun Matru [Inbar and Risso, 2001]. Volcanic activity on Tromen started more than two million years ago (Figure 7). The ${ }^{39} \mathrm{Ar}^{40} \mathrm{Ar}$ ages span the range between circa $2.3 \mathrm{Ma}$ and circa $0.5 \mathrm{Ma}$ (Figure 7). There is only one age less than $0.5 \mathrm{Ma}$, but that is not surprising, because we did not sample the youngest volcanic formations (Basaltos VI and VII). Our youngest age (0.04 $\pm 0.04 \mathrm{Ma}, \mathrm{CB} 03-10)$ and reports of historical activity [Havestadt, 1752; Simkin and Siebert, 1994] suggest that Tromen volcano is still active.

[70] From a histogram, there seem to have been two main periods of volcanic activity (Figure 7). The first period covers the emplacement of sills, domes and dikes at El Paso, ignimbrite on the western flank of the volcano, and basaltic lava flows on both western and eastern flanks. Some of the 

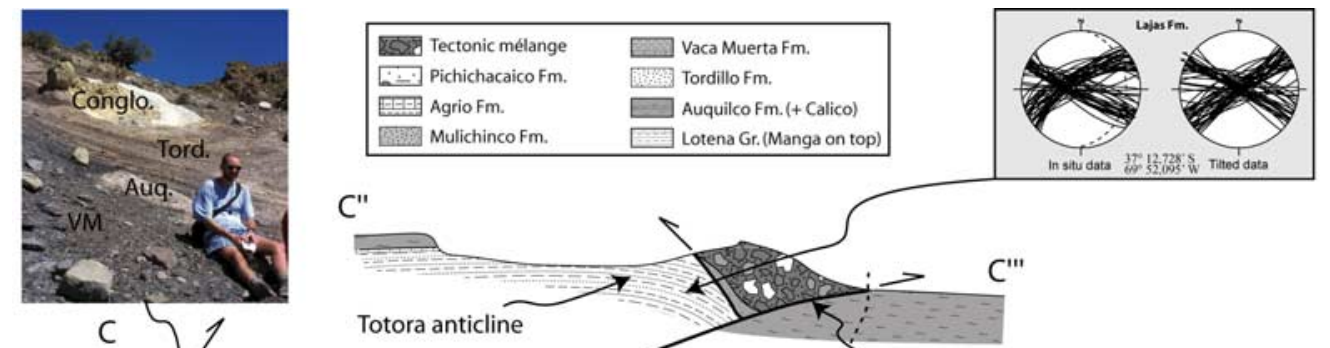

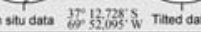

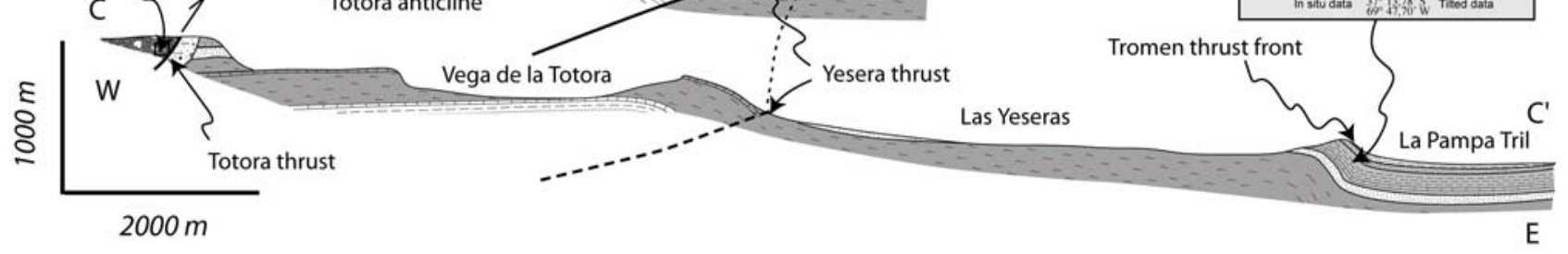

Figure 14. Cross sections at Las Yeseras, eastern flank of Tromen. For location, see Figure 8. Data are compatible with E-W shortening. In Lajas formation, two families of vertical joints are compatible with E-W shortening. Tectonic melange (photograph, left) contains block of Pichichacaico conglomerate (white). Vertical scale is almost twice horizontal scale.

dikes may have been feeding lava flows. Clearly, felsic rocks (andesite, dacite \& rhyolite) appeared together with basaltic rocks, although the former may have been precursors. The basaltic pebbles within the Pichichacaico formation derive from lava of this period, although the age of the conglomerate itself is unconstrained. However, at Cerro Bayo, andesite flows alternated with conglomerates, indicating that significant erosion occurred between eruptions.

[71] The second period of activity at about $1 \mathrm{Ma}$ includes most of the domes at Cerro Bayo and Cerro Tilhué, and one dome at El Paso. During this period, basaltic lavas flowed at Los Barros. Their ages are similar to that of the Cerro Wayle basalts (1.04 $\pm 0.06 \mathrm{Ma}[$ Kay et al., 2006a]), suggesting that their source may have been Cerro Wayle, rather than Tromen.

[72] The conglomerates of the Huecú and Agua Carmonina formations, as well as the calcrete, contain volcanic fragments that are more diverse in origin than those of the Pichichacaico formation. Again, the ages of these formations are unconstrained.

[73] We did not date the Basalto VI and VII formations, but they are likely to be younger than $0.5 \mathrm{Ma}$. Indeed, Kay et al. [2006a] have obtained an $\mathrm{Ar} / \mathrm{Ar}$ age of $0.175 \pm$ $0.028 \mathrm{Ma}$. The flows are relatively thin and less voluminous than the domes and flows of the second period.

\subsection{Structure of Tromen}

[74] Tromen is in a fold-and-thrust belt (Figure 1) [Kozlowski et al., 1996]. Deformed Mesozoic strata crop out in the eroded center of the volcano, at an altitude of about $3000 \mathrm{~m}$, some $2000 \mathrm{~m}$ above the surrounding plain (Figure 15). On the flanks of Tromen, volcanic products are relatively thin. On the western flank, basaltic lava flows are less than $100 \mathrm{~m}$ thick in the lower reaches of the Arroyo Blanco, and 200 to $300 \mathrm{~m}$ thick in its upper reaches. On the eastern flank, domes are about 200 to $300 \mathrm{~m}$ thick at Cerro Bayo (Figure 3). More centrally, volcanic products may be up to $1000 \mathrm{~m}$ thick around the main crater of Tromen, as at Cerro Wayle. We conclude that more than $80 \%$ of the edifice is Mesozoic sedimentary rock (Figure 15) [see Kozlowski et al., 1996; Zapata et al., 1999]. Thus Tromen, like Auca Mahuida to the east [Rossello et al., 2002], is not like a typical shield volcano, resulting from a thick accumulation of lava. Instead, it consists of a thin volcanic cover, upon an uplifted area of sediment. What structurally distinguishes Tromen from Auca Mahuida is that it has been uplifted as a result of compressional deformation.

[75] Within the substrate of Tromen, the main tectonic structures are northerly trending folds and thrusts, which have resulted from E-W shortening (Figure 8). On both western and eastern flanks, these structures verge outward. To the south, their traces curve around the foot of the volcano [Kozlowski et al., 1996; Marques and Cobbold, 2002]. Thus, on the SE flank, the Tromen thrust strikes NNE-SSW; and on the SW flank, all structures strike NNWSSE. According to our new observations, analogous trends hold in the north. Thus, on the NE flank, folds and reverse faults within the Mulichinco and Vaca Muerta formations trend NW-SE; whereas on the NW flank, folds within basalt lavas, faults within pyroclastic deposits, and topographic escarpments, all strike NNE.

[76] In the Neuquén basin in general, both thick-skinned and thin-skinned thrusts have been reported, on the basis of surface and subsurface data [Kozlowski et al., 1996; Zapata et al., 1999]. Thick-skinned deformation is manifest in the Cordillera del Viento, to the west of Tromen [Kozlowski et al., 1996], and in the Sierra de Reyes, to the east [Zollner and Amos, 1973; Holmberg, 1975]. Thin-skinned detachments are common in (1) evaporite of the Auquilco formation, (2) black shale of the Vaca Muerta formation [Kozlowski et al., 1996] and (3) evaporite of the Huitrín formation [Zapata et al., 2001].

[77] On the eastern flank of Tromen, offsets on the Tromen, Yeseras, and Totora thrusts are larger than 


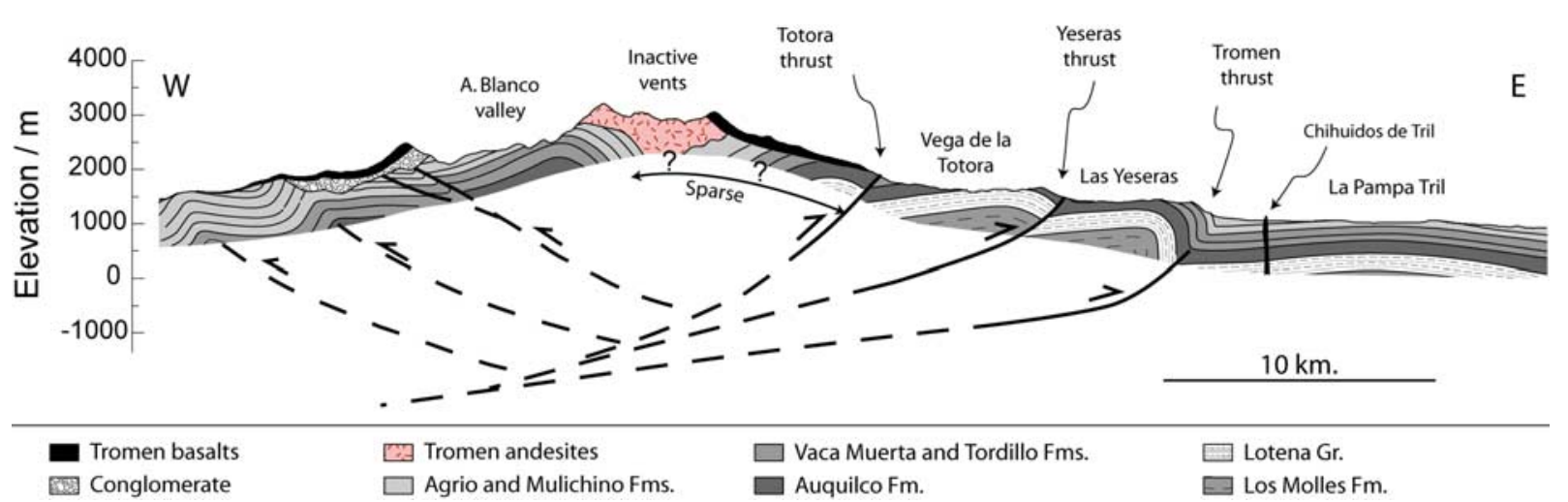

Figure 15. Composite cross section of Tromen volcano. For location, see Figure 2a. Down to $1000 \mathrm{~m}$ below surface, data are well constrained on the deeply incised western flank (Arroyo Blanco, Figure 9) but less so on the eastern flank (Las Yeseras, Figure 14) where basalts cover subsurface features. Deep faults beneath Pampa Tril are constrained by poor seismic data from southern flank [Kozlowski et al., 1996]. Schematic faults (dashed lines) represent our preferred model for the deep structure: an asymmetric pop-up, between eastward verging fore thrusts and westward verging back thrusts. Vertical scale is 1.6 times horizonal scale.

$1000 \mathrm{~m}$ and the sheet dip is about $30^{\circ}$. The oldest rocks to crop out, in the hanging wall of the Tromen thrust, are of the middle Jurassic Lotena group. The Tromen thrust can be seen to continue even deeper on seismic profiles [Kozlowski et al., 1996]. Zapata et al. [1999] have interpreted most of the deformation in terms of basement tectonics, involving reactivation of Jurassic normal faults. In contrast, from outcrop data on the western flank, and from a regional seismic section across the southern flank, Kozlowski et al. [1996, Figure 4] inferred a thin-skinned detachment in late Jurassic shale of the Vaca Muerta formation, reaching under the entire volcano. We cannot rule out this possibility. According to our data for the western flank (Figure 9), the offsets on three reverse faults are smaller than $1000 \mathrm{~m}$, and the sheet dip is about $20^{\circ}$ to the west, slightly steeper than the surface slope. The Early Cretaceous Agrio formation crops out on the lower slope, whereas the late Jurassic Vaca Muerta formation crops out nearer the center of the volcano. Because older rocks do not crop out on this western flank, the reverse faults may indeed root into a thin-skinned detachment near the base of the Vaca Muerta formation. Alternatively, the reverse faults may be more thick skinned. In our preferred model, Tromen has formed above a thick-skinned pop-up, between eastward verging fore thrusts and westward verging back thrusts (Figure 15). To test this model would require further seismic data.

[78] At outcrop, fault slip data and joints, whether in the substrate or in overlying volcanic formations, are broadly compatible with E-W shortening, due allowance being made for variations around the volcano (Figure 9, 10, and 12-14). The dikes at Chihuido de Tril and El Paso, and the lineaments at Cerro Bayo and Cerro Tilhué, are suggestive of hydraulic fracturing, in a context where the least principal stress trends N-S and the greatest stress trends E-W. The dike orientations and the dome alignments are easy to reconcile with our fault slip data, the current state of stress in the Neuquén basin [Guzmán et al., 2005], and the current direction of convergence at the Pacific margin. They may also be indicative of N-S spreading in the hanging wall of the Tromen thrust, under the weight of the volcano [see Johnson, 1970; Marques and Cobbold, 2002, 2006; Galland et al., 2007].

\subsection{Age of Deformation}

[79] On regional evidence, the Tromen thrust was active in the Neogene, during the Quechua phase of Andean orogeny [Cobbold and Rossello, 2003]. Kozlowski et al. [1996] suggested that compressional deformation in the area stopped at 12 Ma. More recently, Folguera et al. [2004], Ramos and Folguera [2005], and Kay et al. [2006a] estimated an early Pliocene age for the last phases of compressional deformation. However, recent compression would better account for offset Quaternary glacial deposits [Zollner and Amos, 1973] and for active folds and faults [Cobbold and Rossello, 2003].

[80] The volcanic products and conglomerates of Tromen are unconformable upon a strongly deformed sedimentary substrate. The amount of shortening in the volcanic cover, although difficult to estimate, is probably less than $10 \%$. Thus most of the shortening in the substrate must have accumulated before $2.27 \pm 0.10 \mathrm{Ma}$, when volcanic activity started.

[81] According to our observations, deformation in the volcanic cover accumulated throughout the late Pliocene to Holocene.

[82] 1. The domes at Cerro Tilhué and Cerro Bayo lie along lineaments trending E-W. If these were fissures that formed by hydraulic fracturing, E-W compression was active between circa $2 \mathrm{Ma}$ and circa $0.8 \mathrm{Ma}$ (Table 1).

[83] 2. The dikes at Chihuido de Tril and in the Arroyo Blanco strike almost E-W. If they formed by hydraulic fracturing under E-W compression, this was active between $2 \mathrm{Ma}$ and 1.6 Ma (Table 1). 
[84] 3. A block of conglomerate, similar in nature to the Pichichacaico formation, forms part of the tectonic breccia next to the Totora thrust. If this conglomerate indeed derives from the Pichichacaico formation, significant tectonic deformation has occurred since $1.83 \pm 0.06 \mathrm{Ma}$ (Table 1).

[85] 4. Although the samples of faulted dikes from the Arroyo Blanco proved to be too weathered for dating, others in the same area, having the same strike and showing minor amounts of faulting, yielded acceptable ${ }^{39} \mathrm{Ar}-{ }^{40} \mathrm{Ar}$ ages. The youngest age being circa 1.6 Ma (Table 1 and Figure 7), shear faulting under E-W compression occurred later than that.

[86] 5. The basaltic lava flows at Los Barros cooled at circa $1 \mathrm{Ma}$ and folded then or later. Assuming that the folds were contemporaneous with long topographic escarpments (Figures 8, 9, and 12), we infer that reverse faulting in the substrate continued after $1 \mathrm{Ma}$.

[87] Although Folguera et al. [2002, 2005, 2006] have advocated recent E-W extension in the area, all the young tectonic structures that we have observed on Tromen are compressional. According to our arguments, E-W compression and shortening were active at various times between circa $2 \mathrm{Ma}$ and circa $1 \mathrm{Ma}$. Cobbold and Rossello [2003] and Guzmán et al. [2005] have argued that they are still active today. Clearly, further work is needed at a regional scale to evaluate the relative importance of extension and compression in space and time in the Neuquén basin.

\subsection{Relationships Between Tectonics and Volcanism}

[88] Lavas of basaltic to more felsic compositions have erupted simultaneously or nearly simultaneously from Tromen in several periods since circa 2.3 Ma (Figure 7). Because Tromen has undergone tectonic shortening, between circa $2 \mathrm{Ma}$ and circa $1 \mathrm{Ma}$ and more recently as well, magmatic intrusions and eruptions have been broadly contemporaneous with deformation. Thus Tromen is one of the first examples where coeval volcanism and thrusting have been documented. El Reventador volcano in Ecuador is another example [Tibaldi, 2005], but from a more transpressional context.

[89] Marques and Cobbold [2001, 2002, 2006] and Branquet and van Wyk de Vries [2001] have suggested that the curvature of folds and thrusts around Tromen may be due to the weight of the edifice. Such a weight induces a radial stress field [Johnson, 1970], which modifies the regional stress field of purely tectonic origin. However, arcuate thrust belts may also result from other mechanisms [Lickorish et al., 2002]. One possibility is detachment on a restricted area of evaporite or shale. For Tromen, this would have to be deeper than the Auquilco formation. Another possibility is that the Tromen thrust has resulted from tectonic inversion of earlier arcuate normal faults. Finally, a possibility of interest in the Andean context is that detachment has occurred on a weak molten body of magma. Physical modeling has shown that this is possible, so long as the magma does not solidify [Galland et al., 2003, 2006, 2007; Galland, 2005], in which case the configuration results in arcuate thrusts. For testing this hypothesis on
Tromen, deep drilling or geophysical surveys might be appropriate methods.

\subsection{Consequences for Magma Transport}

[90] Beneath Tromen, the magmatic plumbing system is not constrained. However, because Tromen grew in a compressional setting, magma is expected to have formed horizontal or gently dipping intrusive bodies or sills [Hubbert and Willis, 1957; Watanabe et al., 1999; Sibson, 2003]. Not all such sills necessarily result from compressional tectonics, but some may do so, even at crustal scale. For example, a seismic profile across the Hercynian thrust belt of SW Spain has revealed a long, thin, gently dipping and highly reflective body, which is probably a mafic sill, emplaced at midcrustal levels [Simancas et al., 2004; Tornos and Casquet, 2005]. So, under compression what are the mechanisms of magma rise through the Earth's crust to the surface?

[91] Some examples of exhumed intrusions indicate what possibly happens at the roots of Tromen. In the Boulder Batholith of Montana, there is good evidence for a close relationship between thrusting and deep intrusion [Kalakay et al., 2001; Lageson et al., 2001]. The main batholith intruded in the hanging wall of the thrust front of the Sevier orogenic belt. The main frontal thrust has an arcuate trace around the batholith, resulting from the emplacement of magma during the formation of the orogenic belt [Lageson et al., 2001]. The batholith is a tabular intrusive body, a few kilometers thick, gently dipping to the west, and subparallel to the thrust [Kalakay et al., 2001]. In the Idaho-Bitterroot Batholith, many intrusions also follow a major thrust [Foster et al., 2001]. Such associations between intrusions and thrusts suggest that during compression, thrust faults could provide a path for magma toward the surface. Physical modeling has also shown that thrusts can control magma transport in a shortening crust [Galland et al., 2003, 2006, 2007; Galland, 2005; Musumeci et al., 2005]. If magma rises along a thrust, it must move horizontally over a large distance, perhaps in the order of kilometers. Under these conditions, Tromen volcano may not lie vertically above its deep source of magma, and we expect significant horizontal transport of magma within the crust.

[92] In the Andes, other volcanoes lying alongside major thrust faults are also associated with arcuate traces of the thrusts, either around the foot of the volcano, or at a slightly bigger scale. Examples are Guagua Pichincha [Legrand et al., 2002] and El Reventador [Tibaldi, 2005] in Ecuador; Taapaca [Clavero et al., 2004] and Socompa [Branquet and van Wyk de Vries, 2001; van Wyk de Vries et al., 2001] in Chile; and Maipo in Argentina [Nullo et al., 1993]. We interpret such associations as possible indicators that these volcanoes have grown during thrusting and we suspect that lateral magma transport along active thrust faults is a common feature within the crust of the Andean volcanic arc.

\section{Conclusions}

[93] In this paper, we have provided structural and geochronological evidence for the growth of a volcano in an active compressional setting. Tromen is a large back-arc 
volcano in the foothills of the Neuquén basin of Argentina. Its substrate consists of deformed Mesozoic sedimentary rocks. Volcanic activity on Tromen started at circa 2.3 Ma or earlier and has continued until today. According to our ${ }^{39} \mathrm{Ar}-{ }^{40} \mathrm{Ar}$ ages, basaltic lavas erupted almost continuously during this period. The latest of these eruptions appear to have been historical, so that Tromen is technically an active volcano.

[94] The more felsic products of Tromen appear to have formed during two main periods. Most of the domes near the center of the volcano erupted during the first period (circa $2 \mathrm{Ma}$ ), whereas most of those on its eastern and southern flanks formed during the second period (circa $1 \mathrm{Ma})$. These products erupted through fissures trending E-W, which presumably formed by hydraulic fracturing, in response to magmatic pressure and $\mathrm{E}-\mathrm{W}$ compression.

[95] On Tromen, basaltic rocks form a thin cover, typically a few hundred meters thick, whereas Mesozoic sedimentary rocks account for about $80 \%$ of the edifice. The sedimentary strata have been tectonically uplifted in a foldand-thrust belt. The main Tromen thrust trends broadly N-S, but bends around the base of the volcano. Tromen appears to be at the center of a wide pop-up, between eastward verging fore thrusts and westward verging back thrusts. The former at least are deep seated. All these tectonic structures appear to have resulted from crustal thickening and dominantly E-W shortening.
[96] The volcanic cover of Tromen is unconformable upon its Mesozoic substrate. Most of the shortening in the substrate occurred before the beginning of volcanic activity. However, the volcanic rocks of Tromen have also recorded a significant amount of E-W shortening (perhaps as much as $10 \%$ ). According to our ${ }^{39} \mathrm{Ar}^{40} \mathrm{Ar}$ ages, tectonic deformation was active at circa $2 \mathrm{Ma}$, and continued after $1 \mathrm{Ma}$. Hence Tromen has been volcanically active while in a compressional tectonic setting.

[97] Although constraints at depth are cruelly missing, we suggest that the Tromen thrust may have provided a lateral path for magma on its way to the surface. Such lateral transport of magma may be common beneath arc volcanoes growing in close association with active thrusts.

[98] Acknowledgments. We are grateful to Total Austral for funding our fieldwork in Argentina and analyses in Rennes. Jean-Paul Thiriet and Christophe Lombard of Total were instrumental in setting up the project, Rodolfo González and Michael Chaix provided expertise in the field, and German Canto was an able assistant. Olivier Galland's salary for his Ph.D. program at Géosciences-Rennes came from the Ministère de l'Enseignement Supérieur et de la Recherche, France. We acknowledge input from an earlier study, involving Eduardo Rossello of Buenos Aires, and funded by CONICET, Argentina. The late Arturo J. Amos introduced PRC to the geology of the area. Xavier Le Coz provided thin sections, and Nuno Rodrigues helped to prepare some of the samples for ${ }^{39} \mathrm{Ar}-{ }^{40} \mathrm{Ar}$ dating. We thank Suzanne Mahlburg Kay and an anonymous reviewer for pertinent comments that helped us to improve parts of the paper.

\section{References}

Allmendinger, R. W., T. E. Jordan, S. M. Kay, and B. L. Isacks (1997), The evolution of the Altiplano-Puna plateau of the central Andes, Annu. Rev. Earth Planet. Sci., 25, 139-174.

Angelier, J. (1984), Tectonic analysis of fault slip data sets, J. Geophys. Res., 89, 5835-5848.

Angelier, J. (1990), Inversion of field data in fault tectonics to obtain the regional stress. III. A new rapid direct inversion method by analytical means, Geophys. J. Int., 103, 363-376.

Boudesseul, N. (1997), Relations entre volcanisme et tectonique dans une chaîne de subduction active: La Cordillère des Andes, Rapport de DEA Dynamique de la Croûte Continentale, 15 pp, Univ. de Rennes 1, Rennes, France.

Branquet, Y., and B. van Wyk de Vries (2001), Effets de la charge des édifices volcaniques sur la propagation de structures régionales compressives: Exemples naturels et modèles expérimentaux, $C . R$. Acad. Sci., Ser. II A, 333, 455-461.

Cheilletz, A., G. Ruffet, C. Marignac, O. Kolli, D. Gasquet, G. Féraud, and J. P. Bouillin (1999), ${ }^{39} \mathrm{Ar}{ }^{40} \mathrm{Ar}$ dating of shear zones in the Variscan basement of the Greater Kabylia (Algeria). Evidence of an eo-Alpine event at $128 \mathrm{Ma}$ (HauterivianBarremian boundary): Geodynamic consequences, Tectonophysics, 306, 97-116.

Clavero, J. E., R. S. J. Sparks, M. S. Pringle, E. Polanco, and M. C. Gardeweg (2004), Evolution and volcanic hazards of Taapaca Volcanic Complex, central Andes of Northern Chile, J. Geol. Soc. London, $161,603-618$

Cobbold, P. R., and E. A. Rossello (2002), Phases of Andean deformation, foothills of Neuquén basin, Argentina, paper presented at 5th International Symposium on Andean Geodynamics (ISAG 2002), Toulouse, France, 16-18 Sept.

Cobbold, P. R., and E. A. Rossello (2003), Aptian to recent compressional deformation, foothills of Neuquén Basin, Argentina, Mar. Petrol. Geol., 20, $429-443$.
Cobbold, P. R., M. Diraison, and E. A. Rossello (1999), Bitumen veins and Eocene transpression, Neuquén basin, Argentina, Tectonophysics, 314, 423-442.

Cruz, C. E., H. J. Villar, and N. G. Muñoz (1996), Los sistemas petroleros del grupo Mendoza en la fosa de Chos Malal, Cuenca Neuquina, Argentina, paper presented at XIII Congreso Geológico Argentino y III Congreso de Exploración de Hidrocarburos, Actas I, 45-60.

de Silva, S. L. (1989), Altiplano-Puna volcanic complex of the central Andes, Geology, 17, 1102-1106.

Dessanti, R. (1973), Descripción geológica de la Hoja 29b, Bardas Blancas (Prov. Mendoza), Bull. 139, 70 pp., Serv. Nac. Min. Geol., Buenos Aires.

Dessanti, R. (1975), Descripción geológica de la Hoja 28b, Malargüe (Prov. Mendoza), Bull. 149, 50 pp., Serv. Nac. Min. Geol., Buenos Aires.

Folguera, A., V. A. Ramos, and D. Melnick (2002), Partición de la deformación en la zona del arco volcánico de los Andes neuquinos $\left(36-39^{\circ} \mathrm{S}\right)$ en los últimos 30 millones de años, Rev. Geol. Chile, 29, $151-165$.

Folguera, A., V. A. Ramos, R. L. Hermanns, and J. Naranjo (2004), Neotectonics in the foothills of the southernmost central Andes $\left(37^{\circ}-38^{\circ} \mathrm{S}\right)$ : Evidence of strike-slip displacement along the AntiñirCopahue fault zone, Tectonics, 23, TC5008, doi:10.1029/2003TC001533.

Folguera, A., V. A. Ramos, T. R. Zapata, M. Spagnuolo, and F. Miranda (2005), Pliocene to Quaternary retroarc extension in the Andes at $35^{\circ}-37^{\circ} 30^{\prime} \mathrm{S}$, in 6 th International Symposium on Andean Geodynamics (ISAG 2002), Extended Abstracts, edited by T. Sempéré, pp. 277-280, IRD, Univ. de Barcelona, Inst. Geol. y Minero de España, Barcelona.

Folguera, A., T. R. Zapata, and V. A. Ramos (2006), Late Cenozoic extension and the evolution of the Neuquén Andes, in Evolution of an Andean Margin: A Tectonic and Magmatic View from the Andes to the Neuquén Basin $\left(35^{\circ}-39^{\circ} \mathrm{S}\right.$ lat. $)$, edited by S. M. Kay and V. Ramos, Spec. Pap.
Geol. Soc. Am., 40, 267-2857, doi:10.1130/ 2006.2407(12).

Foster, D. A., C. Schafer, C. M. Fanning, and D. W. Hyndman (2001), Relationships between crustal partial melting, plutonism, orogeny, and exhumation: Idaho-Bitterroot batholith, Tectonophysics, $342,313-350$

Franzese, J. R., and L. A. Spalletti (2001), Late Triassic-early Jurassic continental extension in the southwestern Gondwana: Tectonic segmentation and prebreak-up rifting, J. S. Am. Earth Sci., 14, 257-270.

Franzese, J., L. A. Spalletti, I. G. Perez, and D. Macdonald (2003), Tectonic and paleoenvironmental evolution of Mesozoic sedimentary basins along the Andean foothills of Argentina $\left(32^{\circ}-54^{\circ}\right.$ S), J. S. Am. Earth Sci., 16 , $81-90$.

Galland, O. (2005), Interactions mécaniques entre la tectonique compressive et le magmatisme: Expériences analogiques et exemple naturel, Mem. Geosci. Rennes, 116, 411 pp., Rennes, France. (Available at $\mathrm{http}: / /$ tel.archives-ouvertes.fr/documents/archives0/ 00/00/84/98/index_fr.html)

Galland, O., J. de Bremond d'Ars, P. R. Cobbold, and E. Hallot (2003), Physical models of magmatic intrusion during thrusting, Terra Nova, 15, 405-409.

Galland, O., E. Hallot, P. R. Cobbold, G. Ruffet, and J. de Bremond d'Ars (2005), Coeval volcanic activity and tectonic shortening, Tromen volcano, Neuquén province, Argentina, in 6th International Symposium on Andean Geodynamics (ISAG 2002), Extended Abstracts, edited by T. Sempéré, pp. $293-$ 296, IRD, Univ. de Barcelona, Inst. Geol. y Minero de España, Barcelona.

Galland, O., P. R. Cobbold, E. Hallot, J. de Bremond d'Ars, and G. Delavaud (2006), Use of vegetable oil and silica powder for scale modelling of magmatic intrusion in a deforming brittle crust, Earth Planet. Sci. Lett., 243, 786-804.

Galland, O., P. R. Cobbold, J. de Bremond d'Ars, and E. Hallot (2007), Rise and emplacement of magma during horizontal shortening of the brittle crust: In- 
sights from experimental modeling, J. Geophys Res., 112, B06402, doi:10.1029/2006JB004604.

Glazner, A. F. (1991), Plutonism, oblique subduction, and continental growth: An example from the Mesozoic of California, Geology, 19, 784-786.

Groeber, P. (1929), Líneas fundamentales de la geología del Neuquén, sur de Mendoza y regiones adyacentes, 110 pp., Minist. de Agric., Dir. General de Minas, Geol. y Hidrol., Buenos Aires.

Gudmundsson, A. (1984), Tectonic aspects of dykes in northwestern Iceland, Jokull, 34, 81-96.

Guzmán, C. G., E. O. Cristallini, G. L. Bottesi, and R. E. Cómeron (2005), Horizontal stress orientation from breakout analysis in the Neuquén basin, in 6 th International Symposium on Andean Geodynamics (ISAG 2002), Extended Abstracts, edited by T. Sempéré, pp. 354-357, IRD, Univ. de Barcelona, Inst. Geol. y Minero de España, Barcelona.

Hamilton, W. B. (1995), Subduction systems and magmatism, in Volcanism Associated With Extension at Consuming Plate Margins, edited by J. L. Smellie, Geol. Soc. Spec. Publ., 81, 3-28.

Havestadt, B. (1752), Mapa geográfico y diario del Padre Bernardo Havestadt (itinerario). En el cual se detallan las provincias, ciudades, sitios, días y leguas que en los últimos meses del año 1751 y primeros meses del año 1752 recorrió, viajando por los dominios de los indios chilenos, el padre Bernardo Havestadt, misionero de la Compañía de Jesús. (Available at http://es.wikisource.org/wiki/ Memorias de Bernardo Havestadt)

Helgason, J., and M. Zentilli (1985), Field characteristics of laterally emplaced dikes: Anatomy of an exhumed Miocene dike swarm in Reydarfjordur, eastern Iceland, Tectonophysics, 115, 247-274.

Hickey, R. L., F. A. Frey, and D. C. Gerlach (1986), Multiple sources for basaltic arc rocks from the Southern Volcanic Zone of the Andes $\left(34^{\circ}-41^{\circ} \mathrm{S}\right)$ : Trace element and isotopic evidence for contributions from subducted oceanic crust, mantle, and continental crust, J. Geophys. Res., 91, 5963-5983.

Hindle, D., J. Kley, E. Klosko, S. Stein, T. Dixon, and E. Norabuena (2002), Consistency of geologic and geodetic displacements during Andean orogenesis, Geophys. Res. Lett., 29(8), 1188, doi:10.1029/ 2001 GL013757.

Holmberg, E. (1975), Descripción geológica de la Hoja 32c, Buta Ranquil (Prov. Mendoza-Neuquén), Bull. 152, 71 pp., Serv. Geol. Minero Argent., Buenos Aires.

Hubbert, M. K., and D. G. Willis (1957), Mechanics of hydraulic fracturing, in Structural Geology, edited by M. K. Hubbert, pp. 175-190, Hafner, New York.

Hutton, D. H. W. (1997), Syntectonic granites and the principles of effective stress: A general solution to the space problem?, in Granite: From Segregation of Melt to Emplacement Fabrics, edited by J. L. Bouchez, D. H. W. Hutton, and W. E. Stephens, pp. 189-197, Kluwer Acad., New York.

Inbar, M., and C. Risso (2001), A morphological and morphometric analysis of a high density cinder cone volcanic field: Payun Matru, south-central Andes, Argentina, Z. Geomorph., 45, 321-343.

Johnson, A. M. (1970), Physical Processes in Geology, 592 pp., Freeman, Cooper, San Francisco, Calif.

Jordan, T. E., W. M. Burns, R. Veiga, F. Pángaro, P. Copeland, S. Kelley, and C. Mpodozis (2001), Extension and basin formation in the southern Andes caused by increased convergence rate: A midCenozoic trigger for the Andes, Tectonics, 20 $308-324$.

Kalakay, T. J., B. E. John, and D. R. Lageson (2001), Fault-controlled pluton emplacement in the Sevie fold-and-thrust belt of southern Montana, J. Struct. Geol., 23, 1151-1165.

Kay, S. M., and P. Copeland (2006), Early to middle Miocene backarc magmas of the Neuquén basin: Geochemical consequences of slab shallowing and the westward drift of South America, in Evolution of an Andean Margin: A Tectonic and Magmatic View From the Andes to the Neuquén Basin $\left(35^{\circ}-39^{\circ}\right.$ S lat. $)$, edited by S. M. Kay and V. Ramos,
Spec. Pap. Geol. Soc. Am., 407, $185-213$, doi:10.1130/2006.2407(09).

Kay, S. M., W. M. Burns, P. Copeland, and O. Mancilla (2006a), Upper Cretaceous to Holocene magmatism and evidence for transient Miocene shallowing of the Andean subduction zone under the norther Neuquén basin, in Evolution of an Andean Margin A Tectonic and Magmatic View From the Andes to the Neuquén Basin $\left(35^{\circ}-39^{\circ}\right.$ S lat. $)$, edited by S. M Kay and V. Ramos, Spec. Pap. Geol. Soc. Am., 407, 19-60, doi:10.1130/2006.2407(02)

Kay, S. M., O. Mancilla, and P. Copeland (2006b), Evolution of the late Miocene Chachahuén volcanic complex at $37^{\circ} \mathrm{S}$ over the transient shallow subduction zone under the Neuquén Andes, in Evolution of an Andean Margin: A Tectonic and Magmatic View From the Andes to the Neuquén Basin $\left(35^{\circ}-39^{\circ} \mathrm{S}\right.$ lat.), edited by S. M. Kay and V. Ramos, Spec. Pap. Geol. Soc. Am., 407, 215-246, doi:10.1130/ 2006.2407(10)

Kendrick, E. C., M. Bevis, R. F. J. Smalley, O. Cifuentes, and F. Galban (1999), Current rates of convergence across the central Andes: Estimates from continuous GPS observations, Geophys. Res. Lett., 26, $541-$ 544

Kendrick, E., M. Bevis, R. Smalley Jr., and B. Brooks (2001), An integrated crustal velocity field for the central Andes, Geochem. Geophys. Geosyst., 2(11), doi:10.1029/2001GC000191.

Klotz, J., G. Khazaradze, D. Angermann, C. Reigber, R. Perdomo, and O. Cifuentes (2001), Earthquake cycle dominates contemporary crustal deformation in central and southern Andes, Earth Planet. Sci. Lett., 193, 437-446.

Kozlowski, E. E., C. E. Cruz, and C. A. Sylwan (1996) Geología estructural de la zona de Chos Malal, Cuenca Neuquina, Argentina, paper presented at XIII Congreso Geológico Argentino y III Congreso de Exploración de Hidrocarburos, Buenos Aires.

Lageson, D. R., J. G. Schmitt, B. K. Horton, T. J. Kalakay, and B. R. Burton (2001), Influence of Late Cretaceous magmatism on the Sevier orogeni wedge, western Montana, Geol. Soc. Am. Bull., $29,723-726$

Lamb, S., L. Hoke, L. Kennan, and J. Dewey (1997), Cenozoic evolution of the central Andes in Bolivia and northern Chile, in Orogeny Through Time, edited by J.-P. Burg and M. Ford, Geol. Soc. Spec. Publ., 121, 237-264.

Legrand, D., A. Calahorrano, B. Guillier, L. Rivera, M. Ruiz, D. Villagomez, and H. Yepes (2002), Stress tensor analysis of the 1998-1999 tectonic swarm of northern Quito related to the volcanic swarm of Guagua Pichincha volcano, Ecuador, Tectonophysics, 344, 15-36

Lickorish, W. H., M. Ford, J. Bürgisser, and P. R Cobbold (2002), Arcuate thrust systems in sandbox experiments: A comparison to the externa arcs of the Western Alps, Geol. Soc. Am. Bull., 114, 1089-1107

Llambías, E. J., and C. W. Rapela (1988), Las volcanitas de Collipilli, Neuquén $\left(37^{\circ} \mathrm{S}\right)$ y su relación con otras unidades paleógenas de la cordillera, Rev Asoc. Geol. Argent., 44, 224-236.

Llambías, E. J., M. Palacios, and J. C. Danderfer (1982), Las erupciones holocenas del volcán Tromen (Provincia del Neuquén) y su significado en un perfil transversal E-O a la latitud de $37^{\circ} \mathrm{S}$, paper presented at Quinto Congreso Latinoamericano de Geologia, Buenos Aires.

Manceda, R., and D. Figueroa (1995), Inversion of the mesozoic Neuquén Rift in the Malargüe fold and thrust belt, Mendoza, Argentina, in Petroleum Basins of South America, edited by A. J. Tankard, R. Suárez and H. J. Welsink, AAPG Mem., 62, 169 182.

Marques, F. O., and P. R. Cobbold (2001), Topographic controls on deformation partitioning, decoupling and vertical-axis rotations in thrust belts: Insights from sandbox modelling, paper presented at European Geosciences Union 11 Meeting, Strasbourg, France.
Marques, F. O., and P. R. Cobbold (2002), Topography as a major factor in the development of arcuate thrust belts: Insights from sandbox experiments, Tectonophysics, 348, 247-268.

Marques, F. O., and P. R. Cobbold (2006), Effects of topography on the curvature of fold-and-thrust belts during shortening of a 2-layer model of continental lithosphere, Tectonophysics, 415, 65-80.

Marrett, R., and S. H. Emerman (1992), The relations between faulting and mafic magmatism in the Altiplano-Puna plateau (central Andes), Earth Planet. Sci. Lett., 112, $53-59$.

Matteini, M., R. Mazzuoli, R. Omarini, R. Cas, and R. Maas (2002a), Geodynamical evolution of central Andes at $24^{\circ} \mathrm{S}$ as inferred by magma composition along the Calama-Olacapato-El Toro transversal volcanic belt, J. Volcanol. Geotherm. Res., 118, 205-228.

Matteini, M., R. Mazzuoli, R. Omarini, R. Cas, and R. Maas (2002b), The geochemical variations of the upper Cenozoic volcanism along the CalamaOlacapato-El Toro transversal fault system in centra Andes $\left(\sim 24^{\circ} \mathrm{S}\right)$ : Petrogenesis and geodynamic implications, Tectonophysics, 345, 211-227.

Muñoz, J., R. Troncoso, P. Duhart, P. Crignola L. Farmer, and C. R. Stern (2000), The relation of the mid-Tertiary coastal magmatic belt in south-central Chile to the late Oligocene increase in plate convergence rate, Rev. Geol. Chile, 27, 177-203.

Musumeci, G., F. Mazzarini, G. Corti, M. Barsella, and D. Montanari (2005), Magma emplacement in thrust ramp anticline: The Gavorrano Granite (northern Apennines, Italy), Tectonics, 24 TC6009, doi:10.1029/2005TC001801.

Nullo, F. E., R. Caminos, J. L. Panza, and V. Ramos (1993), Mapa geológico de la Provincia de Mendoza, Serv. Geol. Minero Argent., Buenos Aires.

Pardo-Casas, F., and P. Molnar (1987), Relative motion of the Nazca (Farallon) and South American plates since late Cretaceous time, Tectonics, 6, 233-248.

Petrinovic, I. A., U. Riller, J. A. Brod, G. Alvarado, and M. Arnosio (2006), Bimodal volcanism in a tectonic transfer zone: Evidence for tectonically conrolled magmatism in the southern central Andes, NW Argentina, J. Volcanol. Geotherm. Res., 152, $240-252$

Ramos, V. A., and M. Barbieri (1988), El volcanismo cenozoico de Huantraico: Edad y relaciones isotopicas iniciales, provincia del Neuquen, Asoc. Geol. Argent. Rev. 43, 210-223.

Ramos, V., and A. Folguera (2005), Structural and magmatic responses to steepening of a flat subduction, southern Mendoza, Argentina, in 6th International Symposium on Andean Geodynamics (ISAG 2002), Extended Abstracts, edited by T. Sempéré, pp. 592 595, IRD, Univ. de Barcelona, Inst. Geol. y Minero de España, Barcelona.

Renne, P. R., C. C. Swisher, A. L. Deino, D. B. Karner, T. L. Owens, and D. J. DePaolo (1998), Intercalibration of standards, absolute ages and uncertainties in ${ }^{40} \mathrm{Ar} /{ }^{39} \mathrm{Ar}$ dating, Chem. Geol., 145, 117-152.

Rossello, E. A., P. R. Cobbold, M. Diraison, and N. Arnaud (2002), Auca Mahuida (Neuquén basin, Argentina): A Quaternary shield volcano on a hydrocarbon-producing substrate, in 6th International Symposium on Andean Geodynamics (ISAG 2002), Extended Abstracts, edited by T. Sempéré, pp. 549 552, IRD, Univ. de Barcelona, Inst. Geol. y Minero de España, Barcelona.

Ruffet, G., G. Féraud, and M. Amouric (1991), Comparison of ${ }^{40} \mathrm{Ar}-{ }^{39} \mathrm{Ar}$ conventional and laser dating of biotites from the North Tregor Batholith, Geochim. Cosmochim. Acta, 55, 1675-1688.

Ruffet, G., G. Féraud, M. Ballèvre, and J.-R. Kienas (1995), Plateau ages and excess argon in phengites: An ${ }^{40} \mathrm{Ar}^{39} \mathrm{Ar}$ laser probe study of Alpine micas (Sesia Zone, Western Alps, northern Italy), Chem. Geol., 121, 327-343.

Saal, A., F. A. Frey, D. Delphino, and A. Bermudez (1993), Geochemical characteristics of alkalic basalts erupted behind Andean Volcanic Front $\left(35^{\circ}-\right.$ $37^{\circ} \mathrm{S}$ ): Constraints on sources and processes in- 
volved in continental arc magmatism, Eos Trans. $A G U, 74(43)$, Fall Meet. Suppl., 652.

Sibson, R. H. (2003), Brittle-failure controls on maximum sustainable overpressure in different tectonic regimes, AAPG Bull., 87, $901-908$.

Simancas, J. F., et al. (2004), The seismic crustal structure of the Ossa-Morena Zone and its geological interpretation, J. Iber. Geol., 30, 133-142.

Simkin, T., and L. Siebert (1994), Volcanoes of the world: A Regional Directory, Gazetteer, and Chronology of Volcanism During the last 10,000 Years, 2nd ed., 368 pp., Geosci. Press, Tucson, Ariz.

Somoza, R. (1998), Updated Nazca (Farallon)-South America relative motions during the last $40 \mathrm{My}$ Implications for mountain building in the central Andean region, J. S. Am. Earth Sci., 11, 211-215.

Stern, C. R., F. A. Frey, K. Futa, R. E. Zartman, Z. Peng, and T. K. Kiser (1990), Trace-element and Sr, Nd, $\mathrm{Pb}$, and $\mathrm{O}$ isotopic composition of Pliocene and Quaternary alkali basalts of the Patagonian Plateau lavas of southernmost South America, Contrib. Mineral. Petrol., 104, 294-308.

Suarez, M., and C. Emparan (1995), The stratigraphy, geochronology and paleophysiography of a Miocene fresh-water inter-arc basin, southern Chile, J. S. Am. Earth Sci., 8, 17-31.
Tibaldi, A. (2005), Volcanism in compressional tectonic settings: Is it possible?, Geophys, Res. Lett., 32, L06309, doi:10.1029/2004GL021798.

Tornos, F., and C. Casquet (2005), A new scenario for related IOGC and $\mathrm{Ni}-(\mathrm{Cu})$ mineralization: The relationship with giant mid-crustal mafic sills, Variscan Iberian Massif, Terra Nova, 17, 236-241.

Townend, J., and M. D. Zoback (2006), Stress, strain, and mountain building in central Japan, J. Geophys. Res., 111, B03411, doi:10.1029/2005JB003759.

van Wyk de Vries, B., S. Self, P. W. Francis, and L. Keszthelyi (2001), A gravitational spreading origin for the Socompa debris avalanche, J. Volcanol. Geotherm. Res., 105, 225-247.

Vergani, G. D., A. J. Tankard, H. J. Belotti, and H. J. Welsink (1995), Tectonic evolution and paleogeography of the Neuquén basin, Argentina, in Petroleum Basins of South America, edited by A. J. Tankard, R. Suárez, and H. J. Welsink, $A A P G$ Mem., 62, 383-402.

Vergara, M., and F. Munizaga (1974), Age and evolution of the upper Cenozoic andesitic volcanism in central-south Chile, Geol. Soc. Am. Bull., 85, $603-$ 606

Watanabe, T., T. Koyaguchi, and T. Seno (1999), Tectonic stress controls on ascent and emplace- ment of magmas, J. Volcanol. Geotherm. Res., $91,65-78$

Zapata, T. R., I. Brissón, and F. Dzelalija (1999), La estructura de la faja plegada y corrida andina en relación con el control del basamento de la Cuenca Neuquina, Bol. Inf. Pet., 60, 112-121.

Zapata, T. R., F. Dzelalija, and G. Olivieri (2001), Desarrollo de reservorios fracturados de la formación Mulichinco usando modelado estructural 3D: Yacimiento Filo Morado, Cuenca Neuquina, Argentina, Bol. Inf. Pet., 66, 38-47.

Zollner, W., and A. J. Amos (1973), Descripción geológica de la Hoja 32b, Chos Malal (Prov. Neuquén), Bull. 143, 91 pp., Serv. Geol. Minero Argent., Buenos Aires.

P. R. Cobbold, J. de Bremond d'Ars, E. Hallot, and G. Ruffet, Géosciences Rennes (UMR 6118), CNRS, Université de Rennes 1, Campus de Beaulieu, F-35042 Rennes Cedex, France.

O. Galland, PGP, Universitet i Oslo, Physics building, third floor, Sem Selands vei 24, NO-0316 Oslo, Norway. (olivier.galland@fys.uio.no) 